\title{
Tasarım Aktivizmi Bağlamında Konu Odaklı Tasarımcılığın Dijital Platformlarının İncelenmesi
}

\author{
Investigation of Digital Platforms of Subject-Oriented Design in the Context of Design Activism \\ Semih Oduncu, Görsel İletişim Tasarımı Bölümü, Sakarya Üniversitesi
}

\begin{abstract}
Özet
Çevresel politikaların yetersizliğinden doğan ve günlük sonuçları gittikçe daha görünür hale gelen sosyal, ekonomik ve politik sorunlara çözüm arayışları tasarım alanında daha yüksek sesle tartışılmaya başlanmıştır. Daha yaşanabilir bir dünya ülküsüyle tasarım aktivizmi hareketine dahil olan ve aktivist bir yaklaşım gösteren tasarımclar benzer sorunların çözümüne katkı sağlayabilmek amacıyla farklı bakış açılarıyla bir araya gelmektedirler. Özellikle dijital platformlarda bir araya gelen tasarımcların farklı alanlardaki konulara çözüm arayışlarını özetleyen bir başlık olarak Konu Odaklı Tasarım, tasarım literatüründe daha önce kapsamlı şekilde incelenmemiștir. 2020'de tüm dünyayı etkisi altına alan küresel salgından sonra iletişimde dijitalleşmenin çok hızlı şekilde normalleşmesi, çevreci aktivist hareketlerin de dijital platformlardaki varlık sahasını yüksek oranda artırmıștır. Bu çalışmada tasarımda aktivizmin tarihsel gelişimi özetlenmiş ve farklı uzmanlık alanlarındaki aktivist tasarımcıların ortak bir sorunu çözebilmek adına bir araya geldiği dijital platformlar detaylı şekilde incelenmiștir. Ayrıca tasarımda aktivizmin dijital platformlardaki gelişimi ekseninde konu odaklı tasarım kavramı tanımlanmıştır. Konu odaklı tasarımın dijital platformlar aracılı̆̆ıyla aktivizm konusunda sağladığı olanaklar değerlendirilmiştir.
\end{abstract}

Anahtar Sözcükler: Tasarımda aktivizm, sorumlu tasarımcl, farkındalık yaratma, dijital platform, grafik tasarım.

Akademik disipin(ler)/alan(lar): Grafik tasarım, görsel iletişim tasarımı.

\begin{abstract}
The search for solutions to social, economic, and political problems arising from the inadequacy of environmental policies and whose daily consequences are becoming more and more visible has started to be discussed louder in the field of design. Designers who participate in the design activism movement with the ideal of a more habitable environment and show an activist approach come together with different perspectives to contribute to similar problems. SubjectOriented Design is a title that summarizes the search for solutions to issues in various fields, especially by designers who come together on digital platforms, which has not been extensively studied in the design literature previously. After the global pandemic that took hold of the whole world in 2020, the rapid normalization of digitalization in communication has noticeably increased environmental activist movements on digital platforms. In this study, the historical development of activism in design is summarized and digital platforms where activist designers from different specialties come together to solve a common problem have been examined in detail. Besides, in the development of activism in design in digital platforms, the concept of subject-oriented design is defined to the reader. The opportunities provided by Subject-Oriented Design in terms of activism through digital platforms were evaluated.
\end{abstract}

Keywords: Design activism, responsible designer, raise awareness, digital platforms, graphic design.

Academical disciplines/fields: Graphic design, visual communication and design.

- $\quad$ Sorumlu Yazar: Semih Oduncu, Görsel İletișim ve Tasarımı Bölümü, Sakarya Üniversitesi

- $\quad$ Adres: Sanat, Tasarım ve Mimarlık Fakültesi, Sakarya Üniversitesi, Esentepe Kampüsü, Serdivan/Sakarya

- $\quad$ e-posta: semihoduncu@sakarya.edu.tr

- ORCID: 0000-0001-9220-0461

- Cevrimiçi yayın tarihi: 12.06 .2021

- doi: $10.17484 /$ yedi.887788 


\section{Giriş}

Sanayi devriminden günümüze dek gelişen süreçte üretimin hızlanması ile birlikte hayat standartlarının yükselmesi, tüketimin kontrolden çımasına ve insanların tüketebileceklerinden fazlasına sahip olma çabasına girmelerine yol açmıştır. Politik stratejilerin de tüketimi desteklemesi ile sadece çevresel değil, sosyal ve ekonomik problemler ortaya çıkmaya başlamış ve var olan problemler etki alanlarını genişletmiştir.

Ortaya çıkan sorunların karşısında her statüden, meslek ve yaş grubundan duyarlı insanlar, toplumu değiştirmek adına savundukları düşünceleri eyleme dökmeye başlamışlardır. Bu tür aktivist hareketler, tasarımcıların da dahil olmasıyla görsel bir nitelik kazanmıştır. Bir konunun merkezinde toplanan tasarımcıların kendi alanlarının sunduğu imkânlar doğrultusunda sorunun çözümüne katkıda bulunmaları, konu odaklı tasarım kavramının ortaya çıkmasına aracılık etmiştir.

Aktivist tasarımcıların çoğu, teknolojinin olanaklarını kullanmakta ve ideolojileri doğrultusunda dijital platformlarda varlık göstermektedirler. Pandeminin, birçok alanda yarattığı köklü değişimlerden biri olan dijital ortama geçiş hızının artması, tasarımda aktivist hareketlerin de yapısını etkilemiștir. Tasarım alanındaki aktivist grupların etkileşimde kalmaları, yaşanan son gelişmelerden haberdar olmaları ve etki alanlarını genişletmeleri daha dijital bir nitelik kazanmıștır. Dijitalleşme sürecine uyumlanan tasarımda aktivist hareketlerin gelişimini anlayabilmek için üç farklı dijital platform seçilmiştir. Bunlar Sea Shepherd Uluslararası Deniz Yaban Hayatını Koruma Hareketi, Climate Designers (İklim Tasarımcıları) ve Renourish Sürdürülebilir Grafik Tasarım Uygulamaları Platformu'dur. Seçilen üç platformda tasarımın farklı amaçlarla kullanıldığı tespit edilmiş; bu platformlarda tasarımın birbirinden farklı ş̧ekillerde kullanımı örneklendirilmiştir.

Bu araştırma, tasarım aktivizmini dijital açıdan ele almak, konu odaklı tasarım kavramına açıklık getirmek, konu odaklı çalışan tasarımcıların bir araya geldikleri dijital platformları incelemek ve devam eden süreçte bu konu ile alakalı olası araştırmalara ışık tutmak amacıyla yapılmışıı. Dijital platformlarda tasarımda aktivizmin incelenmesinin, konu odaklı tasarım kavramının tanımlanması, aktivist tasarımcıların problemin çözümüne yönelik etkilerinin anlaşılması ve dijital platformun bu açıdan sağladığı avantajların ortaya konulması açısından önem taşımaktadır.

\section{Tasarım ve Tasarımcı Kavramlarının Değişimi}

Günümüzde yaşanan problemlerin temelindeki tüketim alışkanlıkları incelenecek olursa, öncelikle insanları tüketime yönlendiren değişkenlerin neler olduğunun değerlendirilmesi gerekmektedir. Ambalaj tasarımları, reklamlar ve bir ürünü olduğundan daha cazip hale getiren göstergelerin büyük bir çoğunluğu grafik tasarım ürünüdür. Özellikle sanayi ve teknolojinin yükselen devrinde grafik tasarım, toplumu tüketime yönlendiren baş aktör haline gelmiştir. Daha iyi olana sahip olma dürtüsünü körüklemek ve daha fazla tüketmeye teşvik etmek tasarımın temel amacına dönüşmüştür. Bu yolla tasarım, insanları yönlendirme ve onları ikna etme açısından büyük bir etki gücüne sahip olmuş, fakat bu güç çoğunlukla insanları manipüle etmek için kullanılmıştır. Tasarım, sanayi ve ekonominin gelişimi sürecinde, politika tarafından toplumsal yapının inşasında etkin bir șekilde kullanılmış ve bu süreçte tüketime özendirme ve siyasi kararlar doğrultusunda halkı manipüle etme aracı olarak varlık göstermiştir.

Amerikalı grafik tasarımcı ve eğitimci Catherine McCoy (2003, s. 3), politik liderlerin ve stratejilerinin insanları daha çok harcamaya ve tüketime yönlendirdiğini, grafik tasarımcıların da insanların geri kalanıyla aynı pasif hedonizmle yapay refahın ganimetlerini yaşadıklarını belirtmiștir. Fallan'ın (2011, s. 31-32) aktardığına göre benzer düşüncede olan Knut Faegri, 1962 yılında Farmand isimli iş dergisinde yayımladığı Tasarımcı-11. Veba (The Designer - the 11th Plague) isimli makalesi ile dikkat çekmiştir. Faegri'nin eleştirisinin ana fikri, tasarımcıların kendilerini savunan, benmerkezci ve kurnaz oportünistler olmaları, ellerini koydukları her şeyi geçici moda ürünlerine dönüștürmeleri ve aynı zamanda üreticilerin ahlaksız ve sorumsuz sürekli yenilik arayışlarına hizmet edip son derece eleştiriden yoksun davranmaları üzerine biçimlenmiştir.

Buchanan'a göre gücün ve kontrol edebilmenin öncelikli olması, ahlaki amacı doğru olana değil, popüler olana indirgemektedir. Bu durum kötü pazarlamanın, kötü reklamın ve kötü tasarımın yol gösterici ilkesidir (Buchanan, 1998, s. 9). Günümüze dek yaşanan tasarım kirliliği ve tüketim çılgınlı̆̆ göz önünde bulundurulduğunda ahlaki amacın tüketiciyi doğru olana yönlendirmek için kullanılmadı̆̆ çıkarımı yapılabilmektedir. 
Etki gücünün farkına varılması, tasarımcı olmanın da niteliğini değiştirmiştir. Bu konuda araştırmalar yapan Ken Garland ve Viktor Papanek, tasarımcının kendi rolünü keşfedip sorumluluklarının öneminin farkına varması yolunda önemli adımlar atmışlardır.

Ken Garland İlk Önce Öncelikler (First Things First) isimli manifestosunda tasarımcının rolünü sorgulamış ve tasarımcılara, yazarlara ve sanat yönetmenlerine çağrıda bulunmuştur. 1964'te sunulan manifesto, tanınmış fotoğrafçılar, tipograflar, tasarımcılar ve öğretmenlerin oluşturduğu yirmi iki kiși tarafından imzalanmıştır. 1999 sonbaharında ise güncellenerek yeniden yayımlanmıştır (Soar, 2002, s. 573).

Jonathan Barnbrook, bir tasarımda tasarımcının vicdanının da olması gerektiğini ve iletişim niteliği taşıyan her türlü grafik tasarım ürününün topluma karşı bir sorumluluğunun olduğunu savunmuştur. Çoğunlukla çevresel ve kültürel krizleri çalıșmalarının ana konusu olarak belirleyen Barnbrook, tasarımın pazarın taleplerinden bağımsız olduğunun altını çizerek tasarım gücünün toplumu şekillendirmede önemli rolü olduğunu vurgulamıștır (Isparta, 2008). Barnbrook 2000 yllında yenilenen İlk Önce Öncelikler manifestosuna imzasını atan tasarımcılar arasındadır (Barnbrook, 2001).

Avusturyalı tasarımcı ve eğitimci Victor Papanek, yazdığı kitaplar ile tasarımın ve tasarımcının güncel niteliklerini sorgulamış ve bu kavramların rollerini yeniden değerlendirip sosyal, politik, kültürel ve ekonomik alanlarda daha aktif olunması gerektiğini savunmuştur. Papanek, tasarım endüstrisinin gelişen savaş sonrası tüketim kültürünün etkili bir eleştirisini sunmadaki başarısızlığını hesaba katarak, tasarım mesleğini sürdürülebilir aktivizm yoluyla siyasallaştırmayı hedeflemiştir (Clarke, 2013, s. 153) ve bu doğrultuda, tasarımcıların aldıkları etik kararların etki ve sonuçlarının da olacağının unutulmaması gerektiğini vurgulamıștır. Bununla birlikte Papanek, etikten yoksun tasarımı, insanların, onları umursamayan diğer insanların dikkatini çekebilmek veya onlarla yarışabilmek adına ihtiyaç duymadıkları ürünleri, olmayan paralarıyla satın almaya ikna eden çağın en sahte alanı olarak görmüștür (aktaran Ertürk, 2017, s. 732).

Tasarımın ve tasarımcının sosyal açıdan sorumluluklarının olduğu kabul edildiğinde anlamı genişlemekte ve sorumluluğu artmaktadır. Sadece problem çözme aracı olarak değil, aynı zamanda sosyal inovasyona yol açabilecek proaktif bir müdahale, çok disiplinli entegrasyon ve farklı disiplinlerle iş birliği biçimleri yaratan bir duyu oluşturucu olarak tanımlanmaya başlanmaktadır. Tasarımla alakalı tartışmaların kapsamında ve bu tartışmaların ötesinde, akademik araştırmaların ve uygulamaların büyük resmi oluşturan iklim değişikliği, sağlık hizmetleri, eșitsizlik ve eğitim gibi sistematik problemler ile bașa çıkabilmek adına geleneksel tasarım ilkelerini benimsediği görülmektedir (Song ve Lou, 2016, s. 284).

Anlamı genişleyen ve sorumluluğu artan tasarım anlayışının hedefi, sorunları çözmek, ihtiyaçları karşılamak, durumları iyileștirmek, yeni ve yararlı bir șey yaratmaktır. Herbert Simon'ın her şeyi kapsayan tasarım tanımı, tasarım aktivizmi alanına en uygun tanımlama olarak görülmektedir. Bunun sebebi aktivistlerin, profesyonel aktivistlerden aktivizm konusunda çok aktif olmayan bireylere kadar bir dizi statüye göre konumlanabilmeleri ve bu tanımlamanın hepsini kapsayacak nitelikte olmasıdır. Herbert Simon'ın tanımına göre tasarım, profesyonel tasarımcılar ya da diğer bireyler tarafından bilinçli bir şekilde ya da bilmeden uygulanan, mevcut durumdan tercih edilen duruma geçiş eylemidir (Luke, 2009, s. 5). Aynı zamanda kavramsal olarak gelişmeye devam eden tasarım, medya ve reklamı araç olarak kullanan bilgi yapıları arasında, süreçlere kolaylıkla uygulanabilen ve genellenebilir bir disiplin haline gelmektedir (Friedman, 2003, s. 519).

Tasarımın, güncel sorunların çözümüne yönelmesi, toplumsal bilinci ve sosyal inovasyonu destekleyen bir üslup kazanması ile tanımının günümüzde yeniden biçimlenmesi, tasarımcı tanımının da değişmesine yol açmıştır. Bu tanımlamalardan biri Ezio Manzini tarafından yapılmıştır. Manzini'ye göre tasarımcılar bilinçli ya da bilinçsiz bir şekilde, yani her bakımdan tasarım aktivitesi olarak değerlendirilebilecek becerileri ve düşünce biçimlerini uygulayan çok çeşitli sosyal aktörler olarak tanımlanmıştır (Manzini, 2014, s. 62). Manzini'nin yaptığı bu tanımlama Herbert Simon'un tasarım tanımını destekler niteliktedir.

Yapılan tanımlamaların çoğunda tasarım uygulamalarının bilerek ya da bilmeden veya bilinçli ya da bilinçsiz olarak tasarlanmış olabileceğinden bahsedilmiștir. Anlaşılmaktadır ki tasarım sürecinde ve sonucunda ortaya çıkan uygulamaların etik değer taşıması her ne kadar önemli bir gereklilik olsa da aktivist olma endişesi taşıması bir zorunluluk olarak görülmemektedir. Ertürk, tasarımcıların etik konulardaki yaklaşımına değindiği araştırmasında, tasarımcıların çoğu zaman doğruluğuna inanmadıkları bir iletişimi tasarlamak zorunda kalabileceklerinden bahseder. Ertürk'e (2017, s. 731) göre, tasarımcının kendisi ile mesleki rolü uyuşmazlık gösterebilir. Bu uyuşmazlık, tasarımcı, rolünden sıyrılıp kendine döndüğü anda, yani vicdanıyla baş başa kaldığı anda başlar. Bu bağlamda bir tasarımcının etik değerlere uygun 
davrandığının söylenebilmesi için tasarımcı rolüyle birlikte kişiliğinin de onaylayacağı ve yapıcı bir etkiye sahip tasarım anlayışına sahip olması gerekmektedir.

\section{Tasarımda Aktivizmin Politik Tasarım Örnekleriyle Kısa Tarihi}

Araştırma sürecinde incelenen kaynaklarda aktivizm ile ilgili pek çok farklı tanımlama olduğu görülmüştür. Genel açıdan bakıldığında aktivizmin tek bir tanımının olmadığı sonucuna varılsa da, çoğunlukla politika ile birlikte anıldığı ve politik düzenin karşısındaki muhalif eylemleri tanımlamak için kullanıldığına sıkça rastlanmıștır. Bununla birlikte etki ve hareket bu kavramın yapısını doğrudan nitelemektedir. Toplumsal yapıyı pozitif yönde değiştirmek; sosyal, çevresel, ekonomik ve politik sorunlara demokratik çözümler bulmak bu hareketin temel amaçlarını oluşturmaktadır.

Aktivizm kavramı, değişmesi istenen politik ya da toplumsal konularda farkındalık yaratma adına toplu bir şekilde ya da bireysel olarak gerçekleştirilen eylemler bütünü olarak tanımlanmıştır (Köygülü, 2019, s. 74). Her ne kadar politik bir kavram olarak görülse de, aktivizm ile geleneksel siyaset arasındaki çizgi belirsizdir ve koşullara bağlıdır. Aktivizm, geleneksel politikanın ötesine geçen, tipik olarak daha enerjik, tutkulu, yenilikçi ve kararlı olan eylemdir (Martin, 2007, s. 20).

Aktivizmle alakalı geniş tanımlamalardan biri Steve John'a aittir. John'a göre aktivizm, kişilerin, organizasyonların ya da devletlerin ortaya koyduğu, doğru olmadı̆̆ düşünülen ya da uygulanması durumunda ortaya olumsuz sonuçlar doğuracağına inanılan kararlara karşı gerçekleștirilen eylemlerin tanımlanması için kullanılmaktadır. Bu eylemleri gerçekleştiren kişiler ise aktivist olarak tanımlanmaktadır (John'dan aktaran Yıldız, 2019, s. 16).

Bir süreç olarak değerlendirildiğinde aktivizm, herhangi bir durum ya da konu hakkında yaşanan fikir uyuşmazlıkları ve görüş ayrılıkları sebebiyle ortaya çıkan anlaşmazlıklar sonucunda, konuyla alakalı benzer düşüncelere sahip olan bireylerin ortak bir amaç doğrultusunda birleşmeleri, sorun yaşanan kişi ya da grup ile yapılan fikir çatışması sonrasında tarafların anlaşarak konuyu açıklı̆̆ kavuşturması, çözüm bulunması şeklinde ilerlemektedir (Sancar, 2017, s. 3).

Amerikalı yazar, çevreci ve aktivist Paul Hawken, Blessed Unrest isimli kitabının tanıtımını yaptı̆̆ı videoda bütün insanların parçalarını oluşturduğu bütünsel bir hareketten bahsetmektedir. Bu hareketin özellikle beslendiği bir ideoloji ya da savunduğu spesifik bir fikir olmamasına rağmen, bildiklerimizden ya da öğrenebileceklerimizden daha derin, geniş ve daha büyük bir nitelik taşımaktadır. Herhangi bir sınıfa ait olmamakla beraber evrenseldir ve dünyadaki en geniş çeşitliliğe sahiptir. Bir sürü farklı kaynağı olmasına rağmen, kökenini yerel kültür, çevresel konular ve sosyal adalet oluşturmaktadır, o yüzden oluşumunun sadece kural ihlalleri ya da adaletsizlik gibi sorunlarla basite indirgenmemesi gerekmektedir. Asıl amacının dünyanın geleceği için insan hakları hareketi, sivil hakları hareketi ve demokrasi hareketi tabanında yükselen bu oluşum Hawken tarafından isimlendirilmemiştir (captaindarwin, 2012). İsimlendirilmemiş olsa da çevresel, demokratik ve sosyal konulara odaklanan, toplum yapısını kökten değiştirecek bir etki gücüne sahip bu hareketin aktivizm olduğu açıtıtır.

Bununla birlikte aktivizm kavramının, sosyal değişim teorisi, sosyal hareket teorisi, direniş, savunma veya protesto gibi kavramlar düzeyinde teorileştirildiği görülmektedir. Etkin olma ve toplumun inşa edilebilmesi, aktivizmin herhangi bir geçici tanımının merkezinde yer alır. Bu perspektiften aktivizm, değişim için mücadele pratiğini temsil eder ve ilerici olmanın yanı sıra gerici eğilimler ve hedefler tarafından beslenebilir (Cammaerts, 2007, s. 217).

Aktivizmle en çok birlikte anılan kavram olan politikanın sanat ve tasarım ile iş birliği içerisinde olduğu ya da karşı karşıya geldiği dönemlere tarihsel süreçlerde sıkça rastlanmıştır. Grafik tasarımda aktivizmin araştırılabilmesi için öncelikle tarihte siyasal amaçlar için tasarlanan ürünlerin de değerlendirilmesi gerekmektedir çünkü tasarım, aktivizm amacıyla yaygın olarak kullanılmadan önce siyaset aracılığıyla halkı manipüle etmek için kullanılmıştır. Bu kullanımın etkilerinin genişliği, grafik tasarımın politik ve ideolojik düşüncelerin aktarımı açısından ne denli başarılı bir araç olabileceğinin ve tasarımcının da bu gücü hangi rolde kullandığının anlaşılması açısından önemlidir. Dünya savaşlarının hemen sonrasında, aktivist bir hareket niteliği taşıyan, tasarımcıların ahlaki ve etik açıdan kendilerini sorgulamaları için yazılan makalelerin, yayımlanan manifestoların en temel sebeplerinden biri, geçmiște yașanmış zor dönemlerde olaylar karşısında tasarımın kullanım şekli ve tasarımcının tutumudur.

Grafik tasarım tarihi tasarımın birçok farklı ülkede politik bir araç olarak kullanıldığının örnekleri ile doludur. Yakın tarih incelendiğinde bu ilişkinin daha çok propaganda afişleri aracıllğıyla gerçekleștiği görülmektedir. 
Grafik tasarımda aktivizmin gelişimi 1860 'lı yıllardaki Süfrajet (Suffragette) Hareketi'nden enformasyon teknolojilerinin hızla yükseldiği günümüze kadar güçlü bir şekilde devam etmektedir (Luke, 2009, s. 18). Süfrajet Hareketi, ABD ve İngiltere'de ortaya çıkan ve sonrasında farklı ülkelere de yayılmış olan, pasif direniş yollarıyla kadınların seçme ve seçilme hakkını savunan feminist kadın hareketi olarak tanımlanmaktadır (Gürcüm ve Aslan, 2017, s. 1392). Bu hareket 1866'da bașlamıș olsa da, 20. yüzyılın başlarına kadar siyasi gösteri ya da görsel propaganda araçlarında belirgin bir gelişme göstermemiştir (Google Arts \& Culture, t.y.).

Süfrajet Hareketi, sahip olduğu ideolojiyi daha geniş kitlelere yaymak amacıyla grafik tasarımdan faydalanmıştır. Bu dönemde Artists' Suffrage League ismiyle hareketin bir uzantısı daha oluşmuştur. Hareketin bu kolu, 1913'te Amerika'da kadın haklarını destekleyen gruplara afiş tasarımlarıyla destek sağlamıştır. Bu doğrultuda hareketi destekleyen yüksek sayıda afişler, yılbaşı kartları ve kartpostallar gibi tanıtım ürünleri tasarlanmıș ve basılmıştır. Emily Ford, May H. Barker, Clara Billing, Dora Meeson Coates, Violet Garrard, Bertha Newcombe ve Emily J. Harding Andrews bu oluşuma destek veren tasarımcı ve sanatçılardır (Artist Biographies, t.y.). Yapılan afiş tasarımların çoğunda, tasarımcıyla birlikte Artists' Suffrage League ifadesini görmek mümkündür. Harding'in Mahkumlar, Deliler ve Kadınlar! Parlemento için oy kullanamazlar isimli çalışması bu kullanıma örnek olarak gösterilebilir (bkz. Şekil 1).

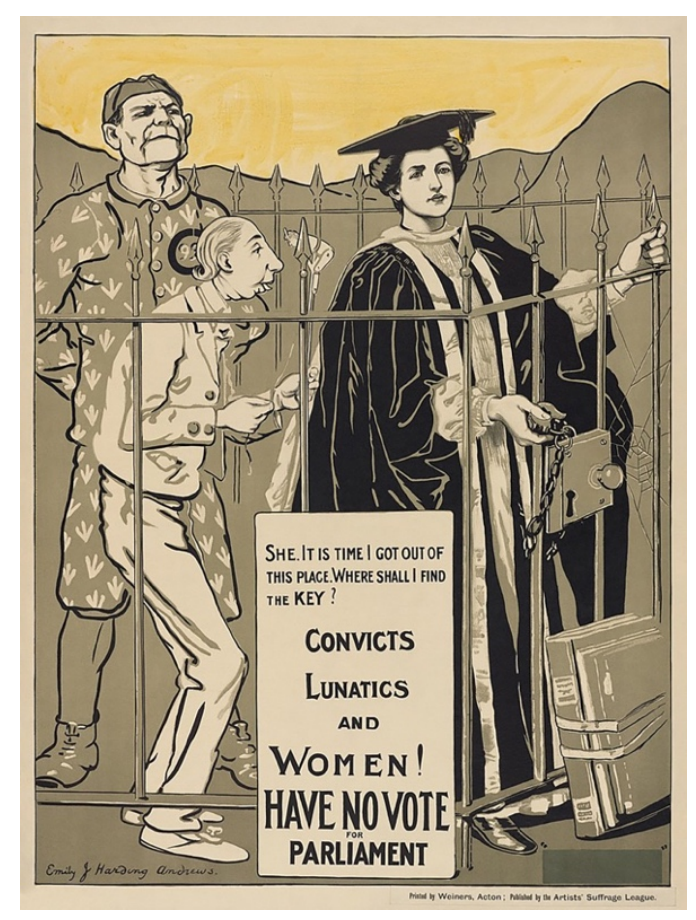

Şekil 1. Mahkumlar, Deliler ve Kadınlar! Parlemento için oy kullanamazlar, E. J. Harding, 1907.

Basılı görsel tasarımın kullanımının en üst düzeye ulaştığı, tasarımın etkisini ve baskısını insanlar üzerinde en fazla hissettirdiği dönemlerin dünya savaşlarının yaşandığı yıllar olduğu bilinmektedir. Afişler, halkın savaş hakkında bilgilendirilmesi ve erkeklerin orduya katılması adına çoğunlukla kahramanlık ya da üstün insan imgeleri kullanılarak tasarlanmıștır. Bu şekilde grafik tasarımın manipülatif gücü propaganda afişleri aracılığı ile toplumu etkisi altına almıştır.

Birinci Dünya Savaşı yıllarında teknolojinin günümüzdeki niteliklere sahip olmaması, radyo ve televizyon gibi kitle iletişim araçlarının yaygınlık kazanmaya başladığı dönemin başında olunması ve baskı teknolojilerinin bu durumun tam aksine yüksek oranda gelişim göstermesi, afiş tasarımını dönemin en etkin kitle iletişim aracına dönüşmesini sağlamıștır. Grafik tasarımın etki gücü bu dönemde kötüye kullanılmış, tarihin en kanlı savaşlarından birini destekleyen bir propaganda aracı haline gelmiştir (Bektaş, 1992, s. 54).

1930'lu yıllarda propaganda terimi, Nazi Propaganda ve Aydınlanma Bakanlı̆̆ı'nın kurulması ile tasarımcıları bu makinenin dişlileri haline getirmiştir. Siyaset için tasarlanan afişlerin manipülatif etki yaratmaları amaçlanmıştır. Günümüzde savaşlarda asker ve tanklar yerine kâğıt ve mürekkeplerin kullanımı ve bu yolla rakiplerin kolektif desteğini yıpratma stratejisi uzun süredir devam etmektedir. (Heller ve Vienne, 2016, s. 50). 
20. yüzyılın başlarında Avrupa'da ve sonrasında Amerika'da birçok tasarımcı modernizmi benimseyerek toplumsal ve politik ilerleme için tasarımın gücünü kullanmış, bu gücü kullanmayı ahlaki bir görev olarak ilke edinmiştir. Toplumsal ilerleme amacıyla ortaya konulan ve 20. yüzyılın başlarındaki devrimler sayesinde ortaya çıkan modernist manifestolar, yazılar ve eserler, grafik tasarımı araç olarak kullanmıştır. Bu dönemde Avrupa ve Amerika'da grafik tasarım, bir amacı kesin ve net bir şekilde gerçekleştirmek için kullanılmıştır: Askeriye ve siviller için propaganda, kamuflaj ve bilgi tasarımı sağlamak (Twemlow, 2008, s. 6). Bu durumda grafik tasarımın politika ile alanlarının ortak bir paydada kesişmesi ve bir propaganda aracı olarak kullanılmaya başlanmasının 20. yüzyılın ilk dönemlerine denk geldiği çıkarımı yapılabilmektedir.

Savaşta tasarımın insanları manipüle etmek için kullanılmış olması, duyarlılığın yitirilmesi ve etiğin hiçe sayılmasının bir göstergesidir. Catherine McCoy (2003, s. 4-5) tasarımda duyarlılığın yitirilmesini farklı bir açıdan değerlendirmiştir. McCoy’a göre, 20. yüzyıl modenizmiyle süregelen ve grafik tasarımın geleceğine biçim veren Bauhaus ve İsviçre ekolünün bazı baskın yönleri vardır. Özellikle Bauhaus'un nesnel rasyonalizmi 19. yüzyll seri üretimde bulunan ve genellikle mimari ve görsel iletişimde görülen duygusal ve karşılıksız eklektizme bir panzehir sağlamıştır. Fakat aynı zamanda bu nesnellik ideali, tasarımcıyı duyarlı endişelerden uzaklaştırmak için de etkisini göstermiştir. Tutkulu bir şekilde özümsenmiş kişisel idealler, soğukkanlı, objektif ve alanında profesyonel olanlar için yersiz görülebilmektedir. Profesyonellerin görüşüne göre fonksiyonellik tanımı çoğu zaman sosyal, ekonomik ya da politik problemlere değil müşterinin kâr payına odaklanmaktadır. Yani bu açıdan değerlendirildiğinde, günümüz koşullarında bir üründen kar elde edilmesi durumu, ürünün fonksiyonel olarak nitelendirilmesi için yeterli ve geçerli bir sebep olarak görülmektedir.

Araştırmanın Tasarım ve Tasarımcı Kavramlarının Değişimi başlığı altında yer verilen tasarımın veba olarak görülecek noktaya gelmesi bu sebeplerle bağlantılıdır. Önce afiş tasarımlarıyla toplumun manipüle edilmesi ve savașa özendirilmesi, ardından savașta açılan yaraların kapatılması bahanesiyle toplumun yine tasarım tarafından, tüketime özendirilerek yozlaşmaya sürüklenmesi, tasarımcıların bazı konularda daha ahlaklı ve etiğe uygun hareket etmeleri gerekliliğini hatta zorunluluğu ortaya koymuştur.

Ken Garland ve Viktor Papanek gibi geniş kitlelerce tanınan ve tasarımcının sorumlulukları hakkında araștırmalar yapan ya da daha sınırlı alana etki eden tasarımcılar sosyal, kültürel veya çevresel konuları tasarımlarının merkezinde konumlandırmaktadırlar. Bununla birlikte bu alanlardaki güncel problemler odağında birçok ulusal ve uluslararası sergilerin, bienal ve trienallerin düzenlendiği de görülmektedir. Bu durum göstermektedir ki tasarım, günümüzde insanların günlük ihtiyaçlarına cevap veren bir araç olmanın yanında farklı alanlarla kurduğu iş birliğiyle var olan sorunların çözümünde de etkin ve güncel bir rol oynamaktadır.

Tasarımcıların da var olan düzen içerisinde yanlış olduğunu düşündükleri ya da topluma, çevreye ve insan haklarına faydalı olacak şekilde değiştirmek istedikleri sistem, düşünce veya işleyişler için itici güç haline gelebilmek adına harekete geçmeleri tasarımda aktivist bir nitelik kazanmalarını sağlamıștır. Bu durum aynı zamanda tasarımda aktivist hareketlerin bașlangıcını da temsil etmektedir. Özellikle enformasyon teknolojsi devrimiyle iletişim kanallarının dijital bir altyapı kazanması bu aktivist hareketlerin etkisini arttırmış ve yayılımını hızlandırmıştır.

İnsanlık tarihinde birçok farklı dönemde görülen enformasyon devrimi özellikle 20. yüzyılın ikinci yarısından itibaren başlayan iletişim ve enformasyon alanında meydana gelen teknolojik gelişmeler doğrultusunda daha belirgin bir nitelik kazanmıștır. Daniel Bell, David Harvey ve Manuel Castells gibi toplumbilimciler özellikle iletişim alanındaki teknolojik gelişmelerin yeni bir toplum modeli ortaya çıkardığı görüşünü savunmuşlardır. Bilgi toplumu, sanayi sonrası toplum, kapitalizm sonrası toplum gibi kavramlarla dile getirilen bu toplum türünde ortak bir bilgi ekonomisinin hâkimiyeti fikri esas alınmıştır (Yaylagül, 2018, s. 21). Bilgi ekonomisinin dinamikleri ise dijital kanallar aracılığıyla bir ağ oluşturmakta ve bu ağ ile yayılım sağlamaktadır.

Baskı tekniklerinin kullanıldığı dönemden bu yana tasarımda aktivizmin tarihsel sürecini, ortaya koyulan çıktılar odağında incelemek mümkündür. İlk çıktılar iletişim teknolojilerinin henüz gelişmeye başladığı ve bu doğrultruda yoğunlukla baskı teknikleri kullanılarak elde edilen poster veya ilan gibi tasarımlardır. Devam eden süreçte ise radyo ve televizyonun geniş kitlelere ulaşarak baskı tekniklerine göre daha geniş bir ağ yaratma süreci başlamıştır. Günümüzde ise bu çıktılar enformasyon teknolojilerinde yaşanan gelişmelerle dijitalleşmiştir. Buradan yola çıkarak tarihsel süreçte tasarımda aktivist hareketlerdeki gelişimin Süfrajet Hareketi'nde ve dünya savaşları sırasında poster ve kartpostal gibi belli ölçeklerde tasarlanıp basılan çıktılarla başladığı, billboard tasarımı gibi daha büyük ölçeklerde sesini duyurmaya devam ettiği, televizyon ve radyo programlarında kendine yer geniş yer bulduğu ve günümüzde bilgi teknolojilerinin geldiği son noktada slaktivist nitelik kazandığı anlaşılmaktadır. 
Slaktivizm; bireylerin internet teknolojilerini kullanarak duygu düşünce ve tepkilerini ifade etme biçimleri yani dijital aktivizmdir (Yegen, 2014, s. 85). Toplumsal tepkileri tetikleyen olayların yaşanması, aktivist hareketlerin oluşumunu hızlandırdıkça kitlelerin ortak bir olaya tepki göstermek için haberleşerek organize bir şekilde bir araya gelme süreleri kısalmıș, paylaşımları büyük oranda artmış ve süreç kolaylaşmıştır. Aktivizmdeki bu teknolojik gelişimin geçmişine bakıldığında İkinci Dünya savaşından sonra değişen ve tüketim odağında yeniden biçimlenen toplumun ortaya çıkardığı olumsuz etkilerden beslendiği anlaşılmaktadır. Toplum sadece ürün tüketimi değil bilgi tüketimi konusunda da bir dönüm noktasına gelmiştir. Bu tüketim açlığının karş̧lanması da teknoloji ve enformasyonun gelişimini tetiklemiştir. $\mathrm{Bu}$ şekilde aktivizm, tarihsel gelişiminin dijital dönemine adım atmıştır. Tasarım alanında ise slaktivizmle dijital platformlar duyarlı tasarımcıların için yeni ve pratik bir kendini ifade etme alanı olmuştur.

Baskı alanında olduğu kadar sosyal medyada oluşturdukları aktivist kampanyalarla da çıtılarını görebileceğimiz aktivist hareketlerden biri Tüketimciliğe (consumerism) karşı ortaya çıkan ve tasarım alanında da belirginleșen Adbusters Dergisi'dir. Vancouver, British Columbia, Kanada'da bulunan Adbusters, ticari güçler tarafından fiziksel ve kültürel çevremizin aşınmasıyla ilgilenen, kâr amacı gütmeyen, okur destekli, 120.000 tirajlı bir dergidir. Çalışmaları Friends of Earth ve Greenpeace gibi kuruluşlar tarafından benimsenmiş, dünya çapında yüzlerce alternatif ve ana akım gazete, dergi, televizyon ve radyo programında yer almıştır (Internet Archive, t.y.). Kendi resmi sitelerinde \#Blackspot Collective ismiyle yayımladıkları bir manifestoları bulunmaktadır ve manifestoda amaçladıkları şeyin demokrasiyi canlandırmak ve sürdürülebilir bir gelecek yaratmak olduğunu belirtmişlerdir (Adbusters, t.y.) Adbusters, dergi olarak varlık gösterse de, Buy Nothing Day ve TVTurnoff Week gibi ortaya koyduğu sosyal kampanyalarla önemli bir aktivist ağ grubu haline gelmiştir (The Influencers, 2005).

Jonathan Barnbrook, Adbusters dergisinin Tasarımda Anarşi (Design Anarchy) başlıklı 37. Sayısını tasarlayarak hem bu aktivist harekete destek vermiş hem de bu hareketle bağlantılı olarak İlk Önce Öncelikler manifestosunun da temalarına vurgu yapan konulara ilişkin tasarımlar ortaya koymuştur. Bunların en bilineni Las Vegas'da, AIGA'nın (American Institue of Graphic Arts) konferans tarihine denk gelecek şekilde sergilenen billboard tasarımıdır. Billboard'un sloganını, "Tasarımcılar, onlar adına yalan söylemenizi isteyen şirketlerden uzak durun (Designers, stay away from corporations that want you to lie for them)" cümlesi oluşturur (bkz. Şekil 2) (Barnbrook, 2001).

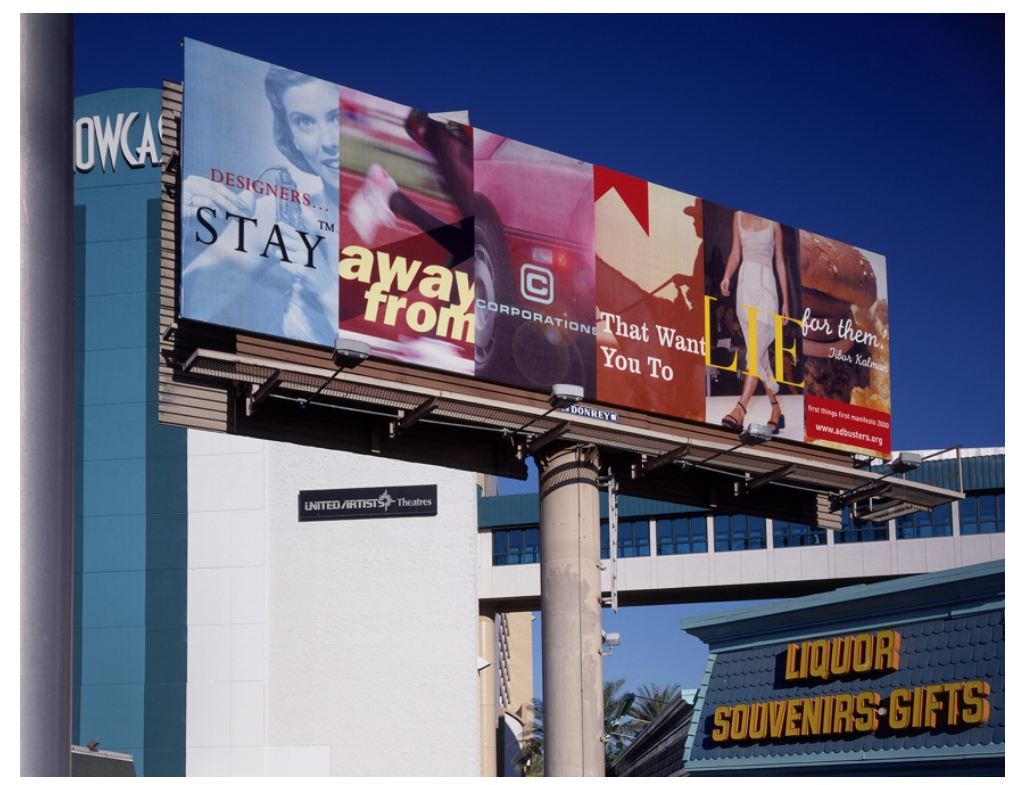

Şekil 2. Designers, stay away from corporations that want you to lie for them, J. Barnbrook, 2001.

2013 yılında Trayvon Martin'in katilinin serbest bırakılması ile kurulan Black Lives Matter Hareketi (Blacklivesmatter, t.y.) slaktivizmin etkin bir şekilde görüldüğü bir toplumsal olay haline gelmiştir. 25 Mayıs 2020 tarihinde George Floyd isimli kişinin bir polis tarafından öldürülmesiyle (George Floyd: What happened in the final moments of his life, 2020) hareket yeniden alevlenmiş, farkındalık yaratma amacıyla grafik tasarım alanında da geniş etki alanına sahip olmuştur. Eşitlik ve adalet konularını tema alan yarışmalar düzenlenmiş, hatta Black Lives Matter Hareketine destek olabilmek adına tasarlanan poster tasarımlarının (bkz. Şekil 3) satışı için internet siteleri olușturulmuştur. 


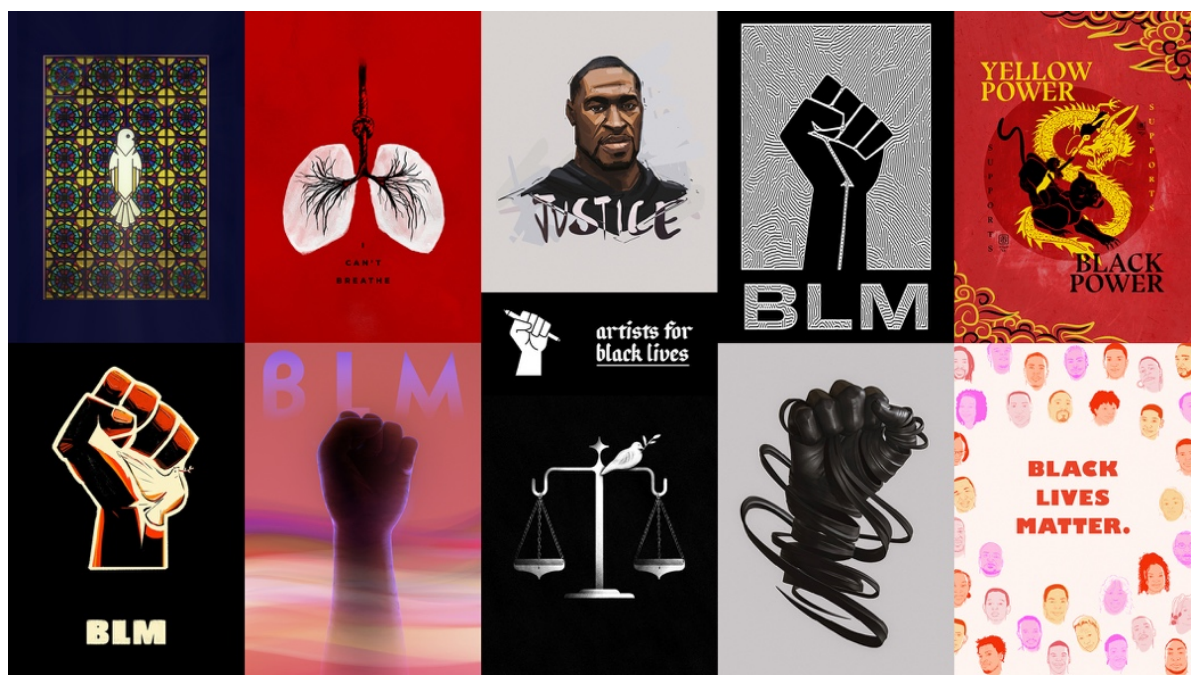

Şekil 3. Black Lives Matter poster tasarımları, 2020 (Skrebneva vd., 2020).

Fransa'da ekonomik adalet hareketi olarak görülen Sarı Yelekliler (Yellow Vests Movement - Gilets Jaunes) (Petrequin, 2018), 2018 yılından bu yana aktif șekilde faaliyet göstermektedir. Sarı Yelekliler Hareketi sanatçlara ve tasarımcılara ilham vermiş, özellikle sokak sanatı, stencil ve poster tasarımlarında yankı bulduğu gözlemlenmiştir. Uluslararası platformlarda tanınan Fransız sokak sanatçısı MTO'da bu hareket için On lâche rien /We don't give up isimli bir çalıșma yapmıștır (bkz. Șekil 4). Bu hareketin birçok imgesi ve karakteri sembol haline gelmiş ve Paris'teki duvarlarda, Caen'de, Montpellier'de, Pyrénées-Atlantiques'te ve hatta Berlin'de sergilenmiștir (Cain, 2019).

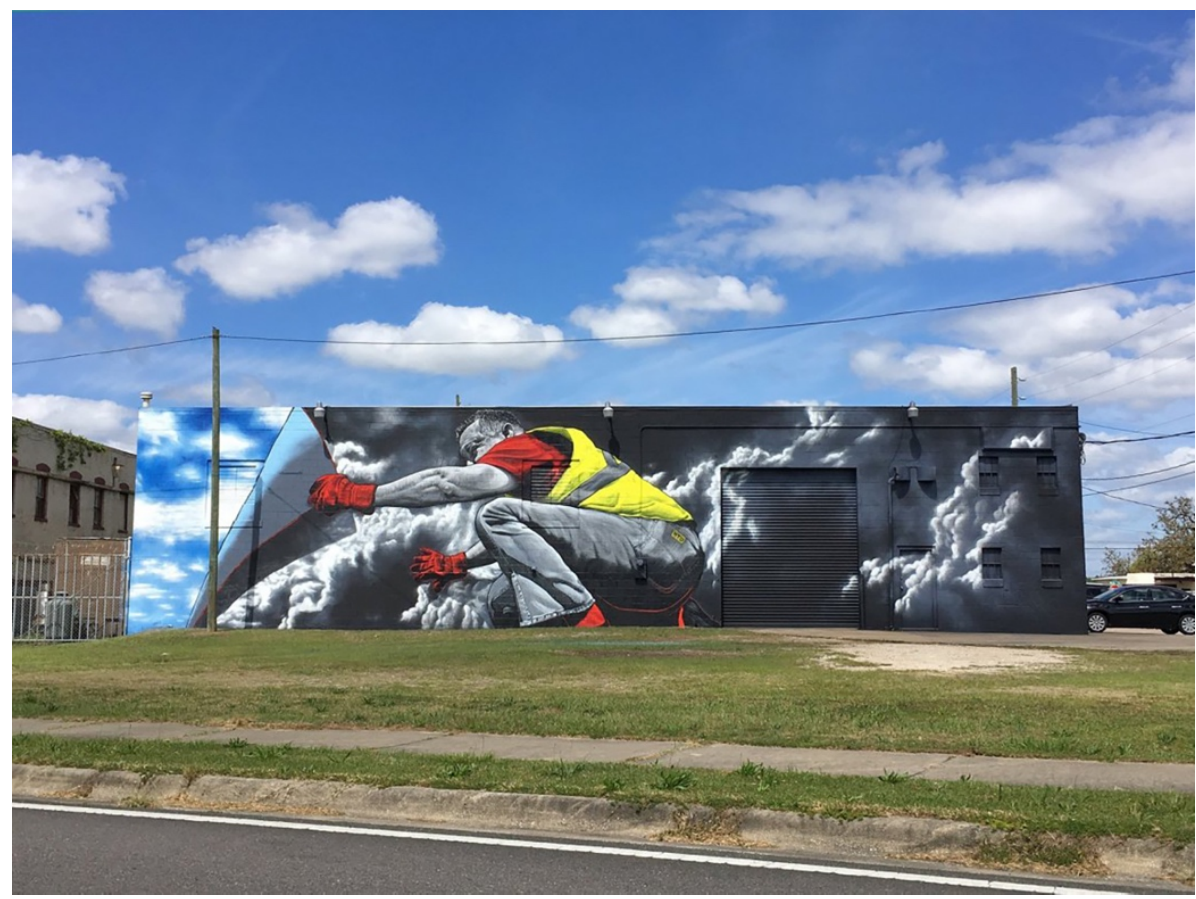

Şekil 4. On lâche rien / We don't give up, MTO, 2019.

Bununla birlikte dijital alanda çalışan birçok illüstratör, photoshop tutkunu ve sanatçllar da bu konu hakkında vermek istekleri mesajları en sevdikleri iletişim aracı olan internet üzerinden paylaşmışlardır (TL Team, 2018)

Bilgisayar, telefon ya da diğer kitle iletişim araçları kullanılarak toplumsal bir olay hakkında fikirlerin ortaya konulması ve bu fikirlerin etrafında birleşilmesi, internet gibi yeni medya kanallarının kullanımının önemine vurgu yapmaktadır. Dijital ortamda tasarımın hem biçimsel hem de uygulama alanlarında kendine 
daha kolay yer edinmesi aktivizmin görsel açıdan desteklemesini de kolaylaştırmaktadır. Artık sokaklardaki pankartların yerini dijital mecradaki hashtagler ve postlardaki görsel tasarım öğeleri almaktadır.

Dijital aktivizm toplumsal olayların ortaya çıkması ya da yeniden alevlenmesinde tasarım alanı dâhilinde olup olmadığı farketmeksizin birçok duyarlı insanın fikirlerini ortaya koyması açısından gelinen son noktadır. Tasarımda ise bu noktadan sonrası, sosyal çevresel ya da politik haksızlıklar karşısında sessiz kalmayan tasarımcıların doğru bir kombinasyon çerçevesinde birleșip olayların çözümü doğrultusunda hareket edecek kanallar oluşturmalarıdır. Konu odaklı tasarım anlayışı çerçevesinde ortaya çıkan dijital platformlar bu alanda atılan ilk adım niteliğindedir.

\section{Tasarımda Aktivizmde Konu Odaklı Tasarımcılık Anlayışı ve Dijital Platformlardan Örnekler}

Her fikir bir konu odağında tasarlanmaktadır ve bu konu toplumsal duyarlılık doğrultusunda sosyal, ekonomik ya da politik olabileceği gibi, ticari amaçlara da hizmet edebilmektedir. Bu araştırmada ise konu odaklı tasarım kavramı, tasarımcıların tek bir konuya yoğunlaşıp o alanda ortaya koydukları tasarımları nitelemek için kullanılmıștır. Konu odaklı tasarım, tasarımda aktivizm ile yakından ilgilidir. Çünkü aktivist tasarımcılar tasarımlarını, karşısında durdukları spesifik problemin odağında biçimlendirmektedir. Yani tasarımı yapılacak olan konu önceden belirlenmiştir. Bu konu etrafında toplanan grafik, endüstriyel, moda ve diğer alanlardan tasarımcılar yeteneklerini sorunu çözmeye kanalize etmişlerdir.

Tasarımın ve tasarımcının merkezinde yükselen aktivist bir hareket kapsamında tasarımcıların bir platformda toplanmalarına ve toplum faydasına olacak bir hareket için güçlerini birleştirmelerine verilebilecek en iyi ve en eski örneklerden biri Süfrajet Hareketi'dir. Tasarımcılar, kadınların seçme ve seçilme hakları ve cinsiyet eşitliği için bir araya gelerek bu problemin odağında tasarımlar yapmışlardır. Tasarlanan bütün posterler, kartpostallar ve diğer tasarım ürünleri kadın haklarına ve cinsiyet eşitliğine atıfta bulunmaktadır. Hareket dahilindeki bütün tasarımcılar sadece bu soruna odaklanmış ve çözüm bulmak için çalışmışlardır. Bu durum konu odaklı tasarımın özünü oluşturmaktadır. Tarihi açıdan değerlendirildiğinde ise Süfrajet Hareketi'nin, tasarımda konu odaklı aktivist hareketlerin ilk örneklerinden biri olduğu çıkarımı yapılabilmektedir.

Süfrajet Hareketi kendi dönem şartlarına göre iletişim kanallarını kullanıp büyük bir etki alanı yaratmıștır. Günümüzde ise teknolojinin ilerlemesi ile birlikte grafik tasarımın yaratım süreçlerinde kullanılan araçlarda belirgin değişiklikler meydana gelmiştir. Kullanılan tekniklerin sınırları genişlemiş, ortaya çlkan sonuçların daha geniş kitlelere ulaşması kolaylaşmış ve belli bir konuda aynı fikirleri paylaşan tasarımcıların ortak bir platformda toplanması ve birbirleriyle iletişim kurmaları da hız kazanmıştır.

Dijital alanlarda görülen gelişmeler, dünya ekonomisinin daha sürdürülebilir temellere oturabilmesi açısından değer taşımaktadır (Crowfoot, 2018). Bu durum tasarımda aktivizm çerçevesinde değerlendirilecek olursa, bir problemin çözümü için çalışan aktivist tasarımcıların, karşı oldukları ya da savundukları ortak konular kapsamında dijital platformlarda kolaylıkla buluşmaları ve daha organize hareket edebilmeleri açısından önem taşımaktadır. Bu nedenle dijital platformlarda oluşum gösteren aktivist grupların sayısı gün geçtikçe artmaktadır.

Konu odaklı tasarımı üç farklı açıdan değerlendirmek mümkündür. Birincisi aktivist bir hareket içerisinde yardımcı rolde kullanılan tasarım, ikincisi aktivist hareketin merkezinde olan tasarım ve son olarak aktivist tasarımcılara rehberlik etme odağında biçimlenen tasarım anlayışıdır. Sea Shepherd Hareketi, aktivist bir harekette tasarımın yardımcı rolünü irdelemek için uygun bir örnektir.

\subsection{Sea Shepherd Uluslararası Deniz Yaban Hayatını Koruma Hareketi}

Sea Sheperd Uluslararası Deniz Yaban Hayatını Koruma Hareketi (Sea Shepherd Protecting Marine Wildlife Worldwide), 1977 yılında Kaptan Paul Watson tarafından Kanada'da tüm deniz yaban hayatını korumak ve sürdürmek amacıyla kurulmuștur (Sea Shepherd, t.y.-a). Hareketin resmî internet sitesi incelendiğinde, farkındalık uyandırmak istenilen konu kapsamında oluşturulan kampanyalara, bu doğrultuda hazırlanan özel tasarımların da eşlik ettiği görülmektedir. Günümüzde güncel olarak devam eden Vaquita Porpoise (Körfez Muturu) Kurtarma, Kaçak, Kontrolsüz ve Yasadışı Balık Avını Önlemek, Yabani Somon Türünün Korunması, Cuvier'in Gagalı Balina Araştırması, Deniz Kaplumbağalarının Korunması ve Okyanus Temizliği (bkz. Şekil 5) kampanyalarının tamamında bu kapsamı imgeleyen logo tasarımları kullanıldığı görülmektedir. 


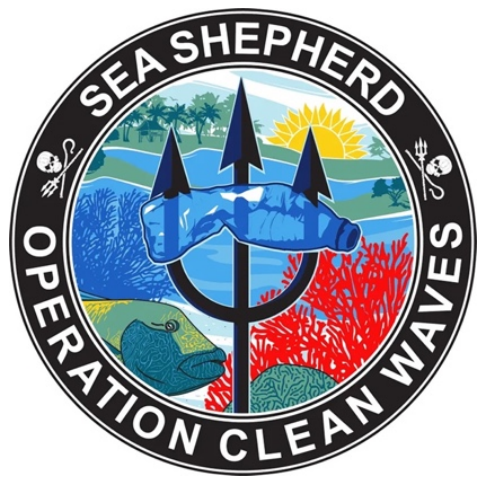

Şekil 5. Okyanus Temizliği Logosu (Sea Shepherd, t.y.-b).

Bununla birlikte Sea Shepherd Hareketi tasarımın gücünü, farklı kampanyalarda dikkat çekmek ve farkındalık uyandırmak amacıyla araç olarak kullanmaya devam etmiştir. Bunlardan biri nesli tükenmekte olan tehlike altındaki hayvanlar hakkında farkındalık yaratma amacıyla tasarlanan Extinction Series (Yok Oluş Serisi) dir. Kampanya, İngiliz tasarımcılar Ed ve James Harrison ortaklığıyla, etkileşimli tasarım tekniği kullanılarak oluşturulmuştur. Tasarımcılar 2015 yılında Under the Skin ismiyle başlattıkları projede Kutup Ayısı, Sunda Pangolin, Forsten Kaplumbağası ve Afrika Fili gibi nesli tükenmekte olan hayvanları konu alan bir koleksiyon tasarlamışlardır. Tasarımda üst katmanda hayvanların dış görünüşleri vektörel illüstrasyon tekniğiyi kullanılarak çizilmiştir. Alt katmanda ise fosforlu kâğıt kullanılarak hayvavanların iskelet yapısının görselleri olușturulmuștur. Daha sonra bu iki çizim ıșıklı bir düzenek üzerine yerleștirilmiștir. Bu șekilde ışıklı düzenek çalıştırıldığında, UV ışığı ile aydınlanan posterin altında fosforlu kâğıttan iskelet görüntüsü ortaya çıkmakta ve nesli tükenmekte olan hayvanların içinde bulundukları tehlikeye vurgu yapılmaktadır. Bu koleksiyona Sea Shepherd kampanyalarından biri olan Vaquita Porpoise Kurtarma kapsamında, Körfez Muturu'da (bkz. Şekil 6) eklenmiștir (sscssite2017, 2017).

Sea Shepherd Hareketi'nin tasarım tekniğinden yardım alarak oluşturduğu bir diğer kampanyayı deniz hayvanlarının kullanıldığı gösterilere karşı insanları bilinçlendirmek için tasarlanan görseller oluşturmaktadır. Bununla birlikte Sea Shepherd Hareketi'nin internet kaynaklarında farkındalık uyandırmak için farklı ajanslar ve tasarımcılarla iş birliği yaparak adını duyurduğu afiş tasarımlarına da ulaşmak mümkündür.

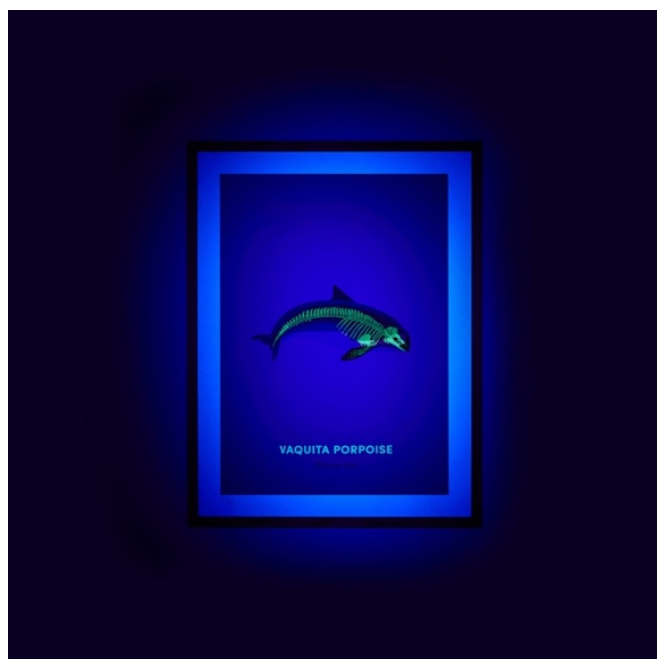

Şekil 6. Vaquita Porpoise Kurtarma kapsamındaki Körfez Muturu çalş̧ması, E. Harrison ve J. Harrison (Vaquita Porpoise, t.y.).

Sea Shepherd Hareketi incelendiğinde, her ne kadar tasarımcıların katkıda bulunduğu ve tasarımın araç olarak kullanıldığı aktivist bir hareket olsa da tasarımın merkezde değil yardımcı rolde olduğu görülmektedir. Çünkü Sea Shepherd bünyesinde sadece tasarımcıların oluşturduğu ve bu platformun belirlediği konularda tasarım yapan bir oluşumun varlığına rastlanmamıștır. 
Küresel ısınma, iklim değişimleri ve sürdürülebilirlik merkezinde oluşan, tasarım ve tasarımcı merkezli dijital platformlar için Climate Designers ve Renourish verilebilecek en uygun örneklerdir. Çünkü Climate Designers uzmanlık alan ayrımı yapmadan bütün tasarımcları kapsayan bir ağ oluşturuyorken Renourish Hareketi sürdürülebilir tasarım odağında görsel ve uygulamalı çözümlemeler için tasarımcılara rehberlik etmektedir.

\subsection{Climate Designers (İklim Tasarımcıları) Platformu}

Climate Designers (İklim Tasarımcıları) platformunda, iklim değişikliğini etkileyen faktörler dikkate alınarak iklim değişiklikleri ve küresel ısınma sorunu odağında tasarım yapma amacı esas alınmıştır. Climate Designers, iklim değişikliği ve küresel ısınma sorunu üzerinde olumlu yönde etkide bulunmak için kendini adayan yaratıcı insanların ve tasarım dünyasındaki profesyonellerinin bir araya geldiği küresel bir merkezdir. Bu hareket, iklim sorununun çözümüne yönelik yeni ve en doğru uygulamalara hâkim olabilmek ve bu hedefte doğru adımları atabilmek adına tasarımın her alanından uzman insanları bir araya getirmektedir. Climate Designers'ın amacı, platformdaki her bir tasarımcının iklim krizinde üzerlerine düşeni yapma konusunda kendilerine güvenmeleri için güç ve bilgi sağlamaktır. Bununla birlikte Climate Designers Platformu resmi internet sitelerinde farklı tasarım alanlarından tasarımcıların bir araya geliş sebeplerinin hayatı bütün insanlar için daha iyi bir hale getirmek olduğunu da belirtmektedir (Climate Designers, t.y.). Odaklandığı konu ve hareketin amacı değerlendirildiğinde bu platformun aktivist bir nitelik taşıdığı söylenebilir.

Dijital platformda, tek bir konuya odaklanan ve tasarımı bir araç olarak kullanan aktivist bir hareketin oluşumunu, dijital platformun avantajlarını ve bu harekete dahil olan aktivist tasarımcların iletişim ağlarının sağladığı avantajları değerlendirebilmek için hareketlerin resmi internet sayfalarını incelemek gerekmektedir (bkz. Şekil 7). Sea Shepherd Hareketi'nden farklı olarak tasarımın ve tasarımcının platformun merkezinde biçimlenmesi dolayısıyla sebep-sonuç ilişkisi içerisinde incelenen Climate Designers Hareketi'nin internet sitesinin yapısı, hareketin kapsamının daha iyi anlaşılmasına yardımcı olmaktadır.

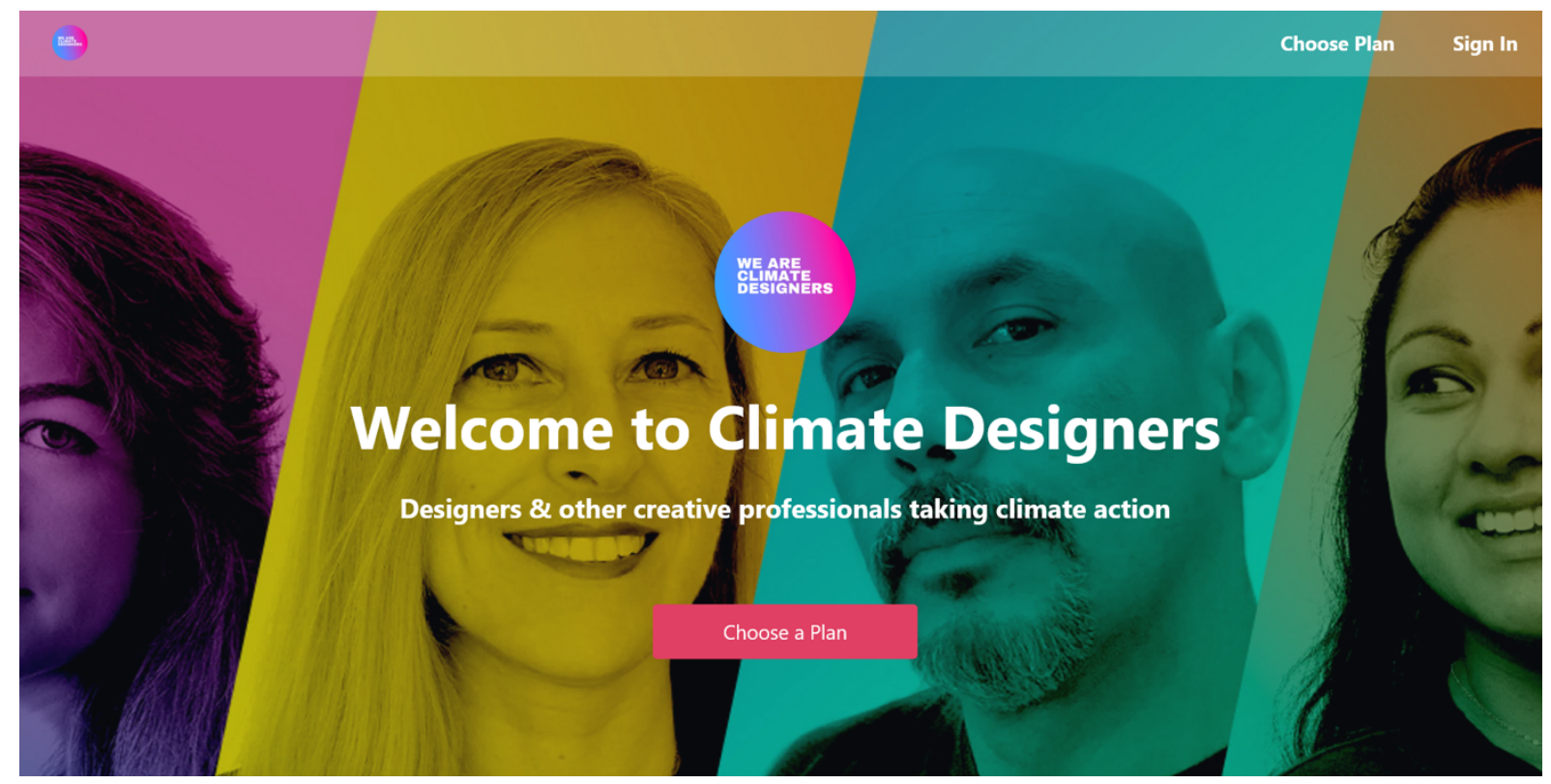

Şekil 7. Climate Designers resmi internet sitesi (Climate Designers, t.y.)

Platformda tasarım alanları birbirinden ayrılmıștır ve birlikte çalışılmak istenen her tasarım alanı için bir sınıf oluşturulmuştur. Biyomimikri, tasarım eğitimi, sistemli düşünme gibi alanından görsel tasarımdaki illüstrasyon, moda tasarımı ve grafik tasarım gibi alanlara kadar birçok tasarımcı, uygulamada sürdürülebilir çözüm ortaklı̆̆ı sunmaktadır.

Climate Designers Almanya, İngiltere, San Francisco, New York, Los Angeles, Latin Amerika, Boston, Bangalore ve Midwest'de varlık göstermektedir. Aynı zamanda ayn bölgede bulunan iklim tasarımcılarının birbirlerini bulabilmeleri adına resmi internet sitelerinde uygulamalar mevcuttur. Uygulamaların yanında tanışma toplantıları düzenlenmekte ve tasarımcıların birbirlerini tanımaları sağlanmaktadır. 
Platformun resmi internet sitesinde, tasarımclların fikir alışveriși yapılabilecekleri alanlardan yeni bilgilerin keşfine kadar birçok farklı konuya yer verildiği görülmüştür. Platforma üye olan tasarımclar bir rehber yardımı ile bilgilendirilmekte ve yönlendirilmektedirler. Ana başlıklar incelendiğinde hareketin amacına, üyelerinin profillerine ve hareketin kapsamına yer verildiği görülmüştür. Dijital platformda belli başlıklara ayrılan konular yapılmak istenen aktiviteye göre sınıflandırılmıştır.

Climate Designers platformundaki Topics sayfasında (bkz. Şekil 8) yeni üyeler için kariyer önerilerinden iklim sözleşmesine, tasarım eğitiminden Covid-19 sürecine kadar birçok konuya yer verilmiştir. Burada üye tasarımcılar, iklim tasarımı ve sürdürülebilirlikle alakalı, diğer tasarımcılara rehberlik edecek bilgiler paylaşmakta ve fikir alışverişi yapmaktadırlar. Bu paylaşımlar aracılığıyla tasarımın bütün alanlarında küresel ısınma, iklim değişimi ya da sürdürülebilirlik ile alakalı gerçekleştirilen projelere ulaşmak mümkün olmaktadir.

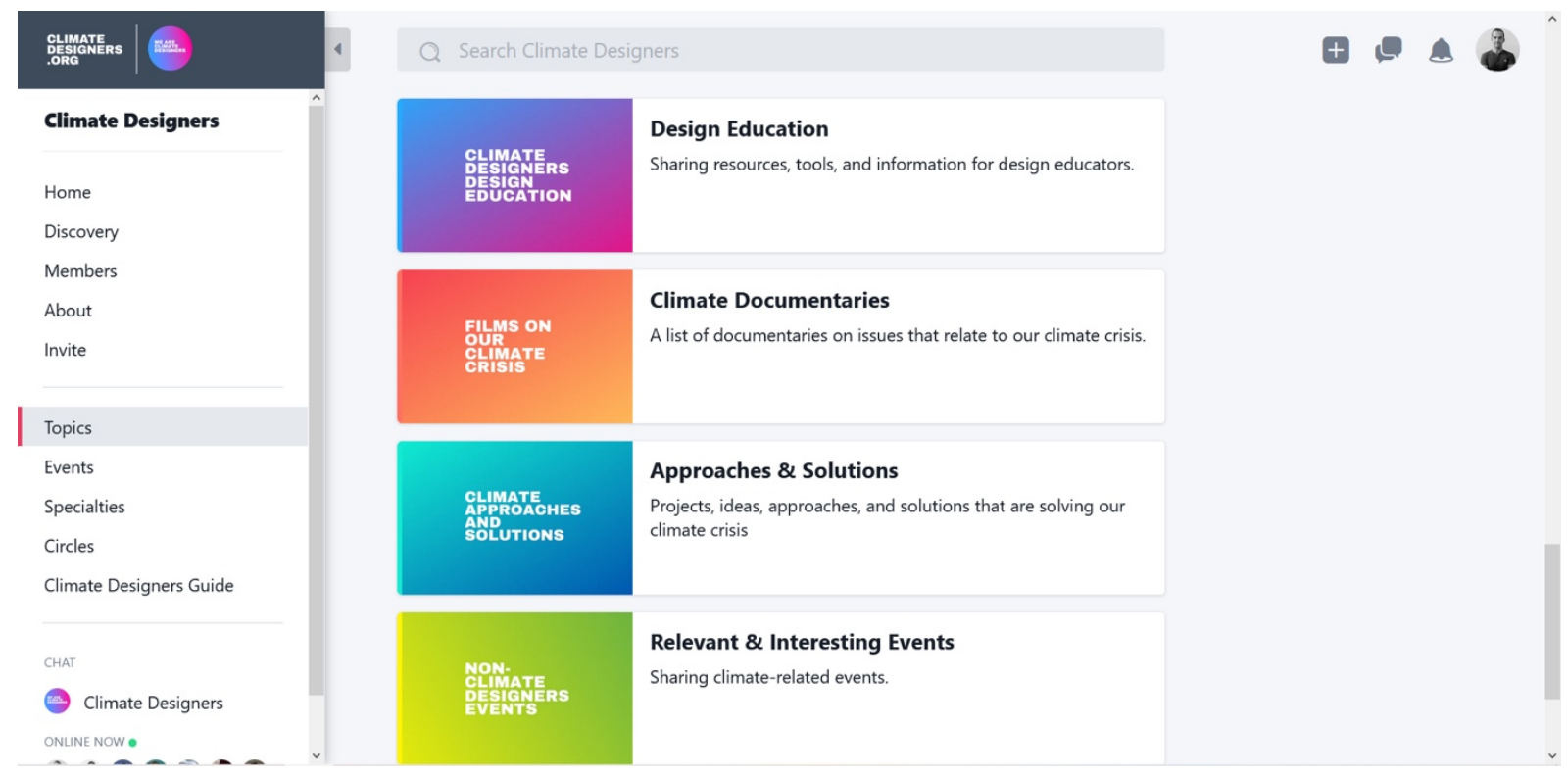

Şekil 8. ClimateDesigners platformu Topics sayfası (We are Climate Designers, t.y.-a).

Platform belli aralıklarla tanışma etkinlikleri düzenlemektedir. Bu tanışma etkinlikleri genelde her ayın üçüncü pazartesi gününde gerçekleșmektedir. Aynı zamanda iklim değișimiyle alakalı bilgilendirme ve tanışma toplantıları, kendi alanında profesyonel birikime sahip bir tasarımcının sürdürülebilir tasarım veya iklim tasarımı gibi konulardaki bilgilerini paylaştığı etkinlikler de düzenlenmektedir. Toplantılar pandemi sürecinde alınması gereken önlemler dikkate alınarak genellikle çevrimiçi olarak Zoom platformu aracılığıyla gerçekleşmektedir.

Climate Designers Platformu'nda, tasarımcıların kendi alanlarında gruplaşabilmesi adına tasarım alanları sınıflandırılmış ve her tasarım için ayrı bir paylaşım alanı açılmıştır (bkz. Şekil 9). Bu sınıflarda üyelerin dahil oldukları tasarım alanlarında gerçekleşen iklim değişimi ve sürdürülebilirlikle alakalı konular paylaşılmaktadır. Bu şekilde, sınıflar aracılığıyla sürdürülebilirlik alanında çevrimiçi verilen eğitimlerin bağlantı adreslerinden, uluslararası üniversitelerde bu konuların ekseninde öğrencilerin tasarladı̆̆ projelerin paylaşımına kadar birçok farklı alanda bilgiye ulaşmak mümkün olmaktadır. Platformda farklı ülkelerdeki İklim tasarımclarının bölgesel haberleri ve etkinliklerin bilgisini alabilecekleri bir sosyal ağ oluşturulmuştur. Aynı zamanda konum bilgisinin paylaşılması durumunda yakın çevrede bulunan diğer iklim tasarımcılarıyla iletişim kurulabilecek özelliklerin olması tasarımcıların aralarında iletişim kurmaları için sağlanan kolaylığa dair ipuçları vermektedir. 


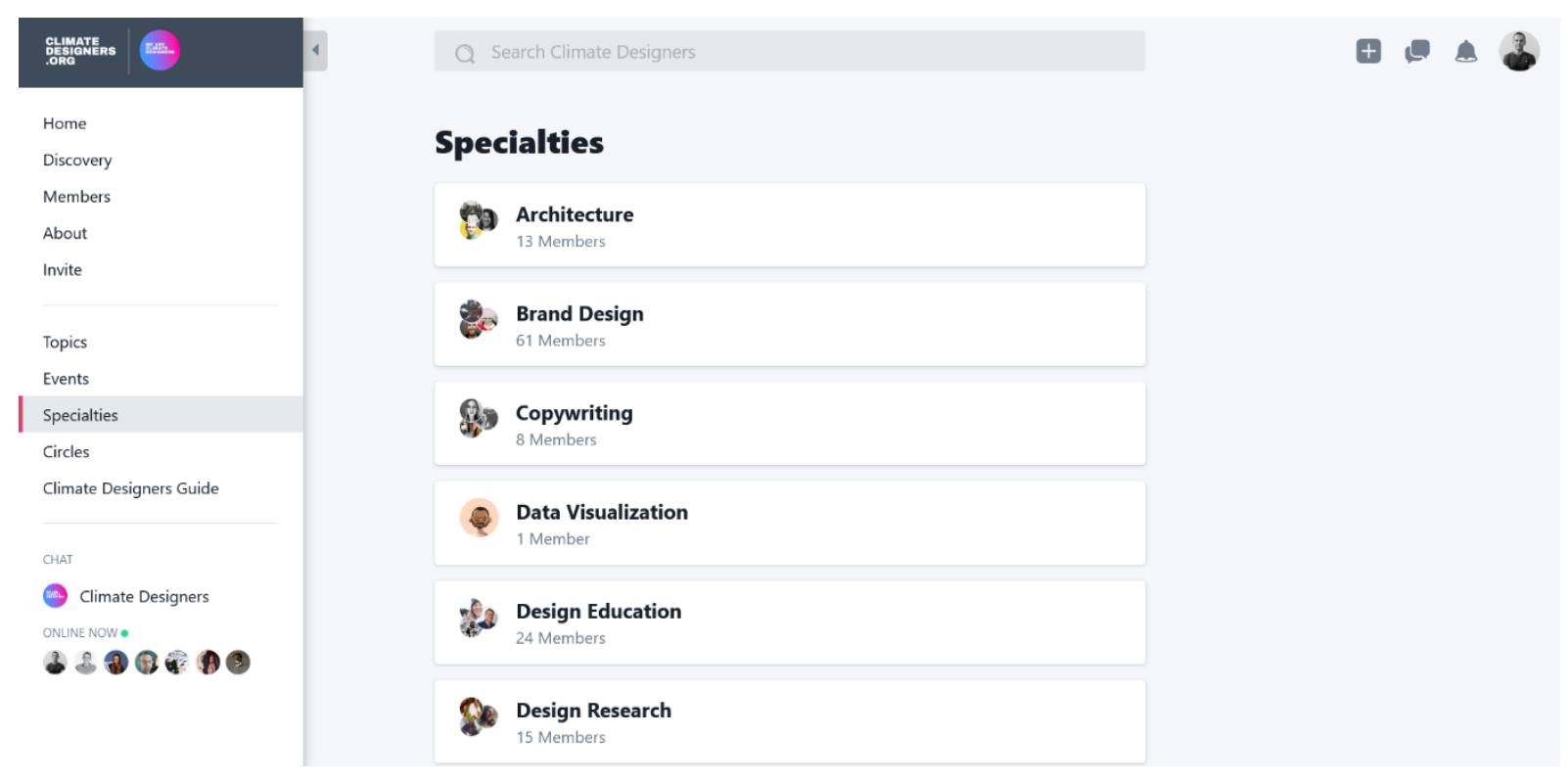

Şekil 9. ClimateDesigners platformu uzmanlık alanları sayfası (We are Climate Designers, t.y.-b).

Bununla birlikte İklim Tasarımcılarının resmi internet sitesi, bazı aktivist tasarımcıların siteleriyle bağlantı kurarak geniş bir ağ oluşturmakta ve iklim hareketine destek veren tasarımcılardan bazılarına ana sayfasında yer vermektedir. Bu şekilde tasarımcılar arasındaki etkileşim de artmaktadır. Climate Designers'a benzer nitelikteki bir diğer aktivist platform ise Fine Acts aktivist tasarım platformudur.

Fine Acts'ın amacı, aktivistleri, eğitmenleri ve sanatçıları bir araya getirmek, farkındalık yaratacak ve harekete geçirmek için itici güç oluştacak sanatsal yaratımlar ortaya koymak ve tasarımcıları bu doğrultuda bilinçlendirmektir. Aynı zamanda insan hakları, sanat ve teknolojinin kesişimini keşfetmek için yeni formatlar tasarlayıp uygulamaktadırlar. Fine Acts'ın aktivist bir nitelik taşımasının bir diğer sebebi, sivil toplum kuruluşlarına yaratıcı düşünme, sanatı kullanma ve oyun kavramını toplumsal değişim için bir araç olarak kullanma konusunda eğitmesidir (Fineacts, t.y.).

Climate Designers'ta olduğu gibi sosyal, politik, ekonomik ya da çevresel sorunlara dikkat çeken projelerin geliştirilmesi, kampanyaların oluşturulması ve tasarımcıların bu noktada birleşmesi yollarıyla çözüm aranmaktadır. Bu açıdan bu iki platformun benzerlik gösterdiği söylenebilir.

\subsection{Renourish Sürdürülebilir Grafik Tasarım Uygulamaları Platformu}

Renourish Sürdürülebilir Grafik Tasarım Uygulamaları Platformu doğrudan aktivist bir tasarım hareketi olmasa da sürdürülebilir tasarım ve küresel ısınma ile alakalı aktivist hareketlere destek veren bir nitelik taşımakta ve buna güncel resmi internet sitesinde de yer vermektedir. Renourish Sürdürülebilir Grafik Tasarım Uygulamaları Platformu bütünsel olarak incelendiğinde, sürdürülebilirlik konusunda farkındalık yaratmak isteyen grafik ve görsel iletişim tasarımcıların ortak bir noktada buluşup karşılaştıkları sorunlara çözüm arayabilecekleri bir platformdur. $\mathrm{Bu}$ açıdan konu odaklı tasarım içerisinde konumlandırılabilmektedir.

Renourish, görsel iletişim tasarımı topluluklarında sürdürülebilirlik ile alakalı düşünce sistemlerini destekleyerek çevrimiçi araçlar, savunma alanı, farkındalık yaratma ve harekete geçme olanağı sunan, kâr amacı gütmeyen bir kuruluştur. Tasarımın aşırı tüketim, israf ve çevredeki doğal sistemleri görmezden gelen, sürdürülemez bir doğrultuda ilerlemesi karşısında Renourish'in amacı; uygulama konusunda aktif olan iletişim tasarımcılarının, eğitimcilerin ve öğrencilerin daha olumlu, daha pozitif, daha yeşil ve pragmatik tasarım kararları almalarına yardımcı olmaktır. Platformda ve blogda yer verilen uygulanmış örnek işler ile tasarımcıların daha sürdürülebilir stratejiler uygulamalarına yardımcı olmak için onlara ilham vermekte ve bilgi kaynağı oluşturmaktadır (Renourish, t.y.-a). Resmî internet sitesi incelendiğinde (bkz. Şekil 10) platformun Tasarımda Sistemsel Düşünce, Tasarım Stratejisi, Araçlar ve Örnek İşler butonları ile tasarımcıları bu bilgilendirecek şekilde tasarlandığı görülmektedir. 

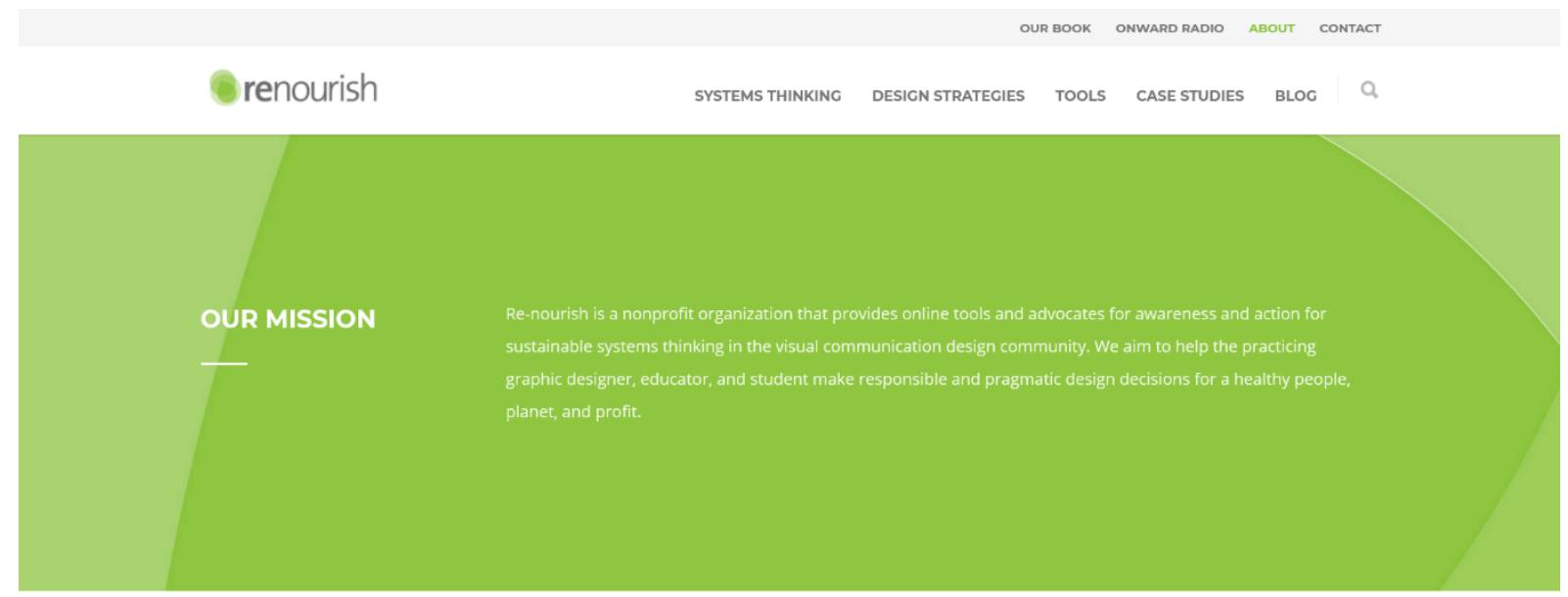

ABOUT RE-NOURISH

Re-nourish is a registered 501(c)(3) nonprofit organization that provides
TRANSPARENCY

TRANOUPARENCY

Şekil 10. Renourish resmi internet sitesi (Renourish, t.y.-a).

Tasarımda Sistemsel Düşünce başlığında, tasarımcının sürdürülebilir bir tasarım ortaya koymak için izlemesi gereken dört farklı adımdan bahsedilmiștir: Proje hedefini belirlemek, tasarım probleminin haritasını çıkarmak, beyin fırtınası ile sonuçlar ortaya koymak ve olası proje sonuçlarını değerlendirmek. Tasarım Strateji bașlığı mürekkep ve baskı, kâğıt ve ambalaj, kullanıcı arayüzü ve kullanıcı deneyimi ve son olarak tasarımda aktivizm konuları hakkında bilgi vermektedir. Araçlar başlığı altında bir projenin uygulama kısmına yönelik alt başlıklara yer verilmektedir. Bunlar geri dönüştürülebilir kâğıt kullanımı, çevre odaklı baskı makinaları gibi teknik kısımları kapsamaktadır. Araçlar başlığı altında en ilgi çeken kısım ise Proje Hesaplama alt başlığıdır. Bu alt başlık altında herhangi bir baskı projesinde israfı en aza indirmek, olumsuz çevresel etkileri azaltmak ve daha az kâğıt kullanarak ekonomik açıdan tasarruf etmek için istenen verilerin sisteme girilmesi ile hesaplama yapılabilmektedir. Son olarak örnek işler başlığında (bkz. Şekil 11) daha önce uygulanan, sürdürülebilir projelere ve ayrıntılarına yer verilmiştir (Renourish, t.y.-a).
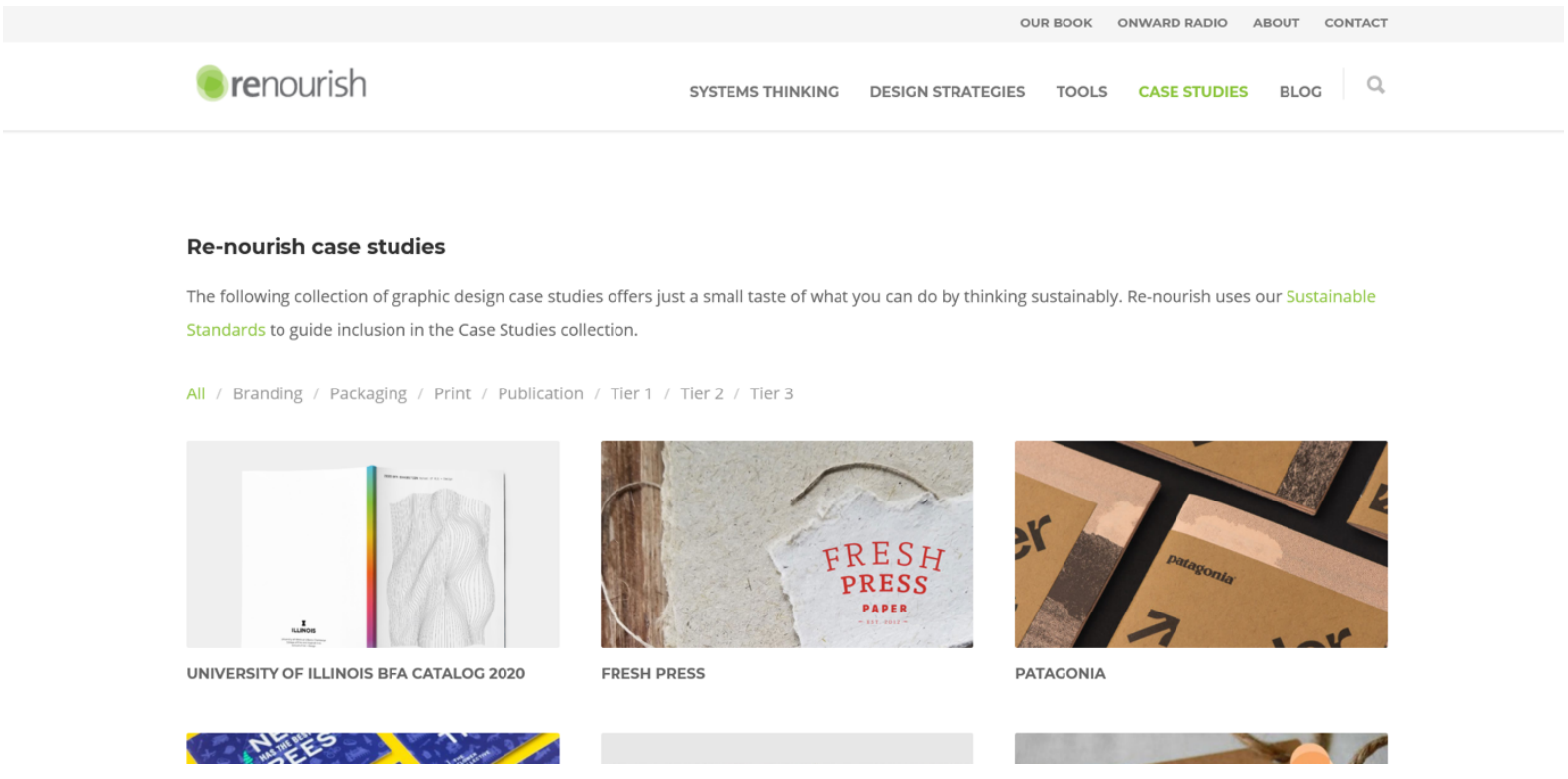

Şekil 11. Renourish örnek işler sayfası (Renourish, t.y.-b).

Platformun Eric Benson ve Yvette Perullo tarafından yazılan bir kitabı da bulunmaktadır. Tam ismi Design to Renourish: Sustainable Graphic Design in Practice olan kitap, sistem odaklı düșünme adı verilen bir tasarım süreci aracılı̆̆ıyla sürdürülebilirliği iş akışlarına entegre etmeye yardımcı olan grafik tasarımcılara 
yönelik bir kitaptır ve grafik tasarımcllara tasarım sürecinde sürdürülebilir olmak için gerçekçi çözümler sunmaktadır (Renourish, t.y.-a).

\section{Sonuç}

Teknolojinin gelişmesi ile çağa ayak uydurabilmekten öte, yaşadığımız dönemin bir zorunluluk haline getirdiği dijital yaklaşımlar, birçok alanda olduğu gibi aktivist hareketlerde de gözlemlenmiștir. Bu entegrasyon, dijital platformlar aracılığıyla aktivist tasarımcıların, dünyanın neresinde olurlarsa olsunlar daha rahat ve kolay etkileşime girmeleri ve hareketi olușturan düşüncenin ve bu doğrultuda ortaya çlkan görsel tasarımların daha fazla insana ulaşması gibi daha da çoğaltılabilecek birçok pozitif gelişimi beraberinde getirmiștir.

Araştırma doğrultusunda tasarımda aktivist nitelik taşıyan hareketlerin dijital platformlarının üç farklı sınıfta incelenebileceği sonucuna varılmıştır. Bunlar tasarımın eşlik ettiği, tasarımın odak noktası olarak belirlendiği ve tasarımda aktivist hareketleri ya da aktivist tasarımcıları yönlendiren platformlardır.

Sea Shepherd Hareketi'nde bir sorunun çözümü için sadece tasarım odaklı planlamalar veya çalışmalar yapılmamış olsa da tasarımın, yardım kampanyalarını destekleyecek nitelikte etkin bir şekilde kullanıldığı görülmektedir.

Climate Designers Hareketi'nin dijital platformunda, farklı alanlardan birçok tasarımcının etkinlikler doğrultusunda bir araya gelmeleri, konu dahilinde paylaşım yapıp bir ağ oluşturmaları daha birçok konuda etkileșimde bulunmaları sistemli bir düzen içerisinde kurgulanmıştır. Bu platform, diğerlerine oranla daha kapsamlıdır. Site içerisinde açılan her yeni alan, tasarımcıların daha etkin ve sistemli ilerleyebilmeleri adına atılmış bir adım niteliğindedir.

Sürdürülebilirliği, meslek etiği olarak çalışma sistemine entegre etmiş grafik tasarımclar için bir rehber olarak tasarlanmış olan Renourish platformunda, grafik tasarımcıların, dijital platformun sağladığı iletişim ve etkileşim konusundaki kolaylıkları, sorunların çözümünde bir araç olarak kullanabilecekleri gözlemlenmiştir.

Seçilen bu platformların kullanımı konusunda ise belirli farklılıkların olduğu açıktır. Climate Designers gibi tasarımın odak noktası olarak belirlendiği hareketlerin dijital platformlarında aktif olmak ve bunlardan faydalanabilmek için tasarımcı olmak gerekiyorken diğer platformlarda bu bir zorunluluk değildir. Örnek olarak Sea Shepherd Hareketi'nde tasarım, oluşturulan kampanyalara görsel kimlik kazandırıyorken, Renourish platformu aktivist grafik tasarımclara daha sürdürülebilir uygulama yöntemleri konusunda rehberlik etmektedir. Yani bir tasarımcı Sea Shepherd Hareketi'ne katılım sağlayıp bu hareket için çalışabilmektedir. Aynısını Renourish platformundan faydalanarak yapması da mümkündür. Fakat tasarım alanı dışında farklı meslek gruplarından birinde çalışan bir aktivist, Sea Shepherd Hareketi'nin yaptığı kampanyalara katılım sağlayabiliyorken, alan dıșı kaldığı için iklim tasarımcıları ya da Renourish platformundan yeteri verimlilikte faydalanamayabilir.

Konu odaklı tasarımın tanımını da bu doğrultuda yapmak mümkün olmaktadır. Konu odaklı tasarım sadece bir konu için tasarım yapmak değil, konuyu merkeze alıp farklı alanda çalışan tasarımcıları bu merkezde birleştirmektir. Bu şekilde disiplinlerarası etkileşim artmakta ve sorunun çözümü için daha fazla adım atılmaktadır. Konu odağında biçimlenen ve meslek gruplarını, belirlenen sorunun çözümü etrafında toplayan dijital platformların sayısının artması, aynı konu için çalışan farklı coğrafyalardan ve meslek gruplarından insanların daha kolay etkileşim kurması ve sorunun çözümünün hız kazanması açısından önem taşımaktadır.

\section{Kaynakça}

Adbusters. (t.y.). \#Blackspot collective manifesto. Erişim adresi: https://www.adbusters.org/campaigns

Artist Biographies. (t.y.). Artists suffrage league. Erişim adresi (15 Şubat 2021): https://www.artbiogs.co.uk/2/organizations/artists-suffrage-league

Barnbrook, J. (2001). Adbusters: First things first. Erişim adresi (3 Şubat 2021): https://www.jonathanbarnbrook.com/work/first-things-first/

Bektaş, D. (1992). Çağdaş grafik tasarımın gelişimi. İstanbul: Yapı Kredi Yayınları.

Blacklivesmatter. (t.y.). About. Erişim adresi (19 Şubat 2021): https://blacklivesmatter.com/about/ 
Buchanan, R. (1998). Branzi's dilemma: Design in contemporary culture. Design Issues, 14(1), 3-20.

Cain, B. (2019, Şubat 08). Comment L'art urbain S'empare des symboles des «gilets jaunes». Le Figaro. Erişim adresi (19 Şubat 2021): https://amp.lefigaro.fr/actualite-france/2019/02/08/0101620190208ARTFIG00299-comment-l-art-urbain-s-empare-des-symboles-des-gilets-jaunes.php

Cammaerts, B. (2007). Activism and media. In Bart, C and Nico, C. (Eds.), Reclaiming the media: communication rights and democratic media roles, Bristol: Intellect. Erişim adresi: http://eprints.lse.ac.uk/39664/

captaindarwin. (2012, Mayıs 24). Blessed unrest: Paul Hawkin [Video]. Youtube. Erişim adresi (12 Şubat 2021): https://www.youtube.com/watch?v=iW8BytViI54

Clarke, J. A. (2013). Actions speak louder. Design and Culture, 5(2), 151-168. Erişim adresi (12 Şubat 2021): https://www.tandfonline.com/doi/abs/10.2752/175470813X13638640370698

Climate Designers. (t.y.). Erişim adresi (22 Şubat 2021): https://www.climatedesigners.org

Crowfoot, A. (2018, 13 Eylül). Designers, stop designing for yesterday's planet. It's Nice That. Erişim adresi (21 Şubat 2021): https://www.itsnicethat.com/news/futurice-design-sustainability-graphicdesign-130918

Ertürk, M. (2017). Sorumluluk kavramı üzerinden görsel iletişim tasarımında etik ve eğitimi. Art-e Sanat Dergisi, 10 (20), 730-742. doi: 10.21602/sduarte.334833

Fallan, K. (2011). The 'designer'-The 11th plague: Design discourse from consumer activism to environmentalism in 1960s Norway. Design Issues, 27(4), 30-42.

Fineacts. (t.y.). Fine Acts is a playground for social change. Erişim adresi (22 Şubat 2021): https://fineacts.co/about

Friedman, K. (2003). Theory construction in design research criteria: Approaches, and methods. Design Studies, 24, s. 507-522. doi: 10.1016/S0142-694X(03)00039-5

George Floyd: What happened in the final moments of his life. (2020, 16 Temmuz). BBC.

Erişim adresi (19 Şubat 2021): https://www.bbc.com/news/world-us-canada-52861726

Google Arts \& Culture. (t.y.). Art \& Woman suffrage. Erişim adresi (15 Şubat 2021): https://artsandculture.google.com/exhibit/art-women-s-suffrage/GQLSZHz8nh2nJA

Gürcüm, H. B. ve Arslan, A. (2017). 19. Yüzyıl süfraj hareketinde sessiz direnișin sembolü olarak reform kıyafeti. Idil Sanat ve Dil Dergisi. 6(32), 1385-1411. doi: 10.7816/idil-06-32-13

Harding, E. J. (1907). Mahkumlar, Deliler ve Kadınlar! Parlemento için oy kullanamazlar [Afiş]. Erişim adresi: https://en.wikipedia.org/wiki/Emily_J._Harding\#/media/File:Convicts_Lunatics_and_Women!_H ave_No_Vote_for_Parliament,_ca._1907-1918.jpg

Heller, S. ve Vienne, V. (2016). Grafik tasarımı değiştiren 100 fikir. İstanbul: Literatür Yayınları.

Internet Archive. (t.y.). Adbusters. Erișim adresi (17 Şubat 2021): https://web.archive.org/web/20111031172500/http://www.adbusters.org/about/adbusters

Isparta, Z. (1 Ağustos, 2008). Jonathan Barnbrook çağdaş tasarımın politik eleştirisi. Türkçe Fotoshop. Erişim adresi (4 Şubat 2020):

https://www.turkcefotoshop.com/dergi/2008/08/jonathan_barnbrook.html

Köygülü, Ö. (2019). Bir dijital aktivizm türü olarak slaktivizm: Lisansüstü öğrenciler üzerine nitel bir araştırma (Yüksek lisans tezi). Ege Üniversitesi Sosyal Bilimler Enstitüsü, İzmir.

Luke, A. F. (2009). Design activism: Beautiful strangeness for a sustainable world. London: Earthscan.

Manzini, E. (2014). Making things happen: Social innovation and design. Design Issues, 30(1), 57-66.

Martin, B. (2007). Activism social and political. In Anderson, G., L. and Herr, K., G. (Eds.), Encyclopedia of Activizm and Social Justice 1 (s. 19-27), California: SAGE Publications.

McCoy, K. (2003). Good citizenship: Design as a social and political force. In Heller S. and Vienne V. (Eds.), Citizen Designer: Perspectives on Design Responsibility (s. 2-8), New York: Allworth Press. 
MTO. (2019). On lâche rien / We don't give up [Mural]. Erişim adresi (9 Haziran 2021): https://nogreywalls.org/mto-supports-the-yellow-vests-movement/

Petrequin, S. (2018, 16 Aralık). Yellow vest protesters still block french traffic circles. AP News. Erişim adresi (19 Şubat 2021): https://apnews.com/article/27ec2dd2c68646ff8ce6801b2b7f6986

Renourish. (t.y.-a). About. Erişim adresi (24 Şubat 2021): https://re-nourish.org/about/

Renourish. (t.y.-b). Re-nourish case studies. Erişim adresi (10 Haziran 2021): https://re-nourish.org/case-studies/

Sancar, G. A. (2017). Aktivist halkla ilişkiler bağlamında WWF dünya saati kampanya örneği. Erciyes İletişim Dergisi, 5(1), 2-18. Erişim adresi: https://dergipark.org.tr/download/article-file/275834

Sea Shepherd. (t.y.-a). Our story. Erişim adresi (21 Şubat 2021): https://seashepherd.org/our-story/

Sea Shepherd. (t.y.-b). Ocean Cleanup. Erişim adresi (10 Haziran 2021): https://seashepherd.org/clean-waves/

Skrebneva, A., Devlin, T., Laag, E., Samson, C., Chu, J., Tian, S., Evans, L., Rubner, G., Knip, P., Vinogradova, S. \& Kuo, S. (2020). Artists for Black Lives [Afiş]. Erișim adresi (10 Haziran 2021): https://www.themill.com/newsfeed/artists-for-black-lives-fundraising-for-the-blm-movement/

Soar, M. (2002). The first things first manifesto and the politics of culture jamming: Towards a cultural economy of graphic design and advertising. Cultural Studies, 16(4), 570-592.

Song, D. ve Lou, Y. (2016). Design activism: Action research as an approach when design meets social innovation. The 10th Conference Of The International Committee For Design History \& Design Studies, 8(2). Erişim adresi: https://www.proceedings.blucher.com.br/article-details/design-activismaction-research-as-an-approach-when-design-meets-social-innovation-24203

sscssite2017. (2017, Aralık 12). Sea Shepherd and under the skin team up for 'extinction series' art prints. Sea Shepherd. Erişim adresi (21 Şubat 2021): https://seashepherd.org/2017/12/12/seashepherd-and-under-the-skin-team-up-for-extinction-series-art-prints/

The Influencers. (2005). Adbusters. Erişim adresi (17 Şubat 2021): https://theinfluencers.org/en/adbusters

TL Team. (2018, 12 Aralık). The 'Gilets Jaunes' movement takes over the internet. Trendland. Erişim adresi (19 Şubat 2021): https://trendland.com/the-gilets-jaunes-movement-take-over-the-internet/

Twemlow, A. (2008). Grafik tasarım ne içindir? İstanbul: YEM Yayın.

Vaquita Porpoise. (t.y.). This print protects: Vaquita Porpoises. Under the Skin. Erişim adresi (21 Şubat 2021): https://undertheskin.co.uk/shop/vaquita/

We are Climate Designers. (t.y.-a). Topics. Erişim adresi (10 Haziran 2021): https://climate-designers.mn.co/topics

We are Climate Designers. (t.y.-b). Specialties. Erişim adresi (10 Haziran 2021): https://climate-designers.mn.co/segments

Yaylagül, L. (2018). Enformasyon toplumunun ekonomi politiği. Iletişim Kuram ve Araştırma Dergisi, 46, 2139. Erişim adresi (31 Mayıs 2021): https://iletisimdergisi.hacibayram.edu.tr/index.php/IKAD/article/view/479/379

Yegen, C. (2014). Bir dijital aktivizm biçimi olarak slaktivizm: Change.org örneği. Karadeniz Teknik Üniversitesi İletişim Araştırmaları Dergisi, 4(2), 84-108. Erişim adresi (31 Mayıs 2021): https://dergipark.org.tr/tr/pub/e-kiad/issue/49299/629878

Yıldız, O. C. (2019). Markaların perspektifinden dijital aktivizm ve dijital aktivizmin marka algısına etkisi (Yüksek lisans tezi). İstanbul Bilgi Üniversitesi Lisansüstü Programlar Enstitüsü, İstanbul. 